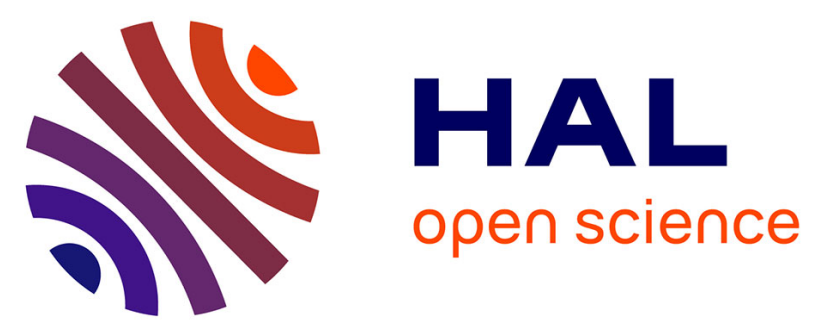

\title{
Fusarium head blight: epidemiological origin of the effects of cultural practices on head blight attacks and the production of mycotoxins by Fusarium in wheat grains
}

Agnès Champeil, Thierry Doré, Jean-Francois Fourbet

\section{To cite this version:}

Agnès Champeil, Thierry Doré, Jean-Francois Fourbet. Fusarium head blight: epidemiological origin of the effects of cultural practices on head blight attacks and the production of mycotoxins by Fusarium in wheat grains. Plant Science, 2004, 166 (6), pp.1389-1415. 10.1016/j.plantsci.2004.02.004 . hal01362219

HAL Id: hal-01362219

https://hal-agroparistech.archives-ouvertes.fr/hal-01362219

Submitted on 10 Sep 2016

HAL is a multi-disciplinary open access archive for the deposit and dissemination of scientific research documents, whether they are published or not. The documents may come from teaching and research institutions in France or abroad, or from public or private research centers.
L'archive ouverte pluridisciplinaire HAL, est destinée au dépôt et à la diffusion de documents scientifiques de niveau recherche, publiés ou non, émanant des établissements d'enseignement et de recherche français ou étrangers, des laboratoires publics ou privés.

\section{(1) (1) $\$$}

Distributed under a Creative Commons Attribution - NonCommercial - NoDerivatives 44.0 
3 Review - Fusarium head blight: epidemiological origin of the effects of cultural practices on head blight attacks and the production of mycotoxins by Fusarium in wheat grains

Champeil A., Doré T. and Fourbet J.F.

UMR of Agronomy INRA INA-PG, 78850 Thiverval-Grignon, France

champeil@grignon.inra.fr, dore@inapg.inra.fr, fourbet@grignon.inra.fr

Abstract

Fusarium head blight is an ancient disease and is very common throughout the world. In this article, we review current knowledge concerning the effects of cultural practices on the development of head blight and the production of toxins in the field. The qualitative effects of these practices on the severity of the disease and/or the production of toxins are in the process of being elucidated but, in many cases, detailed studies have not yet been carried out or conflicting results have been obtained. However, it should be noted that these effects have not yet been quantified. Three different cultural practices are today considered to be of prime importance for combating this disease and the production of mycotoxins: deep tillage, the choice of the preceding crop in the rotation and the choice of appropriate cultivar, as varietal

Keywords: head blight, Fusarium, Microdochium, wheat, cropping systems, mycotoxins

\section{Contents}

$28 \quad 2-\quad$ Effects of various cultural practices on the disease.

29 3- Effects of various cultural practices on the production of mycotoxins by Fusarium ...... 24

Conclusion 


\section{Introduction}

Head blight is a fungal disease affecting many small-grain plant species worldwide [1-10]. Affected wheat grains are small, light (the kernel is degraded), wrinkled and sometimes covered with a white or pink down. Rings or oval stains with brown edges and clear centres may be visible on the back of the grain $[1,2,6,11-13]$ and on the external surface of the glumes (Figure 1). Head blight results from the development of a complex of two genera of pathogenic fungi: Microdochium and Fusarium [8,14-22]. Microdochium consists of a single species, $M$. nivale, made up of two subspecies: $M$. nivale nivale and $M$. nivale majus. Fusarium consists of five main species ( $F$. graminearum, F. culmorum, F. avenaceum, $F$. poae and $F$. triticum), with several strains per species. The most common of these species are $F$. graminearum and $F$. culmorum [2,4,5,23-27], which are also the most pathogenic, reducing the size of the grains and the final yield [24,28].

\section{The consequences of head blight contamination}

This disease was first described at the end of the 19th Century in England [29] and has economic consequences. Yield losses (flower abortion, decrease in grain weight, highly damaged grains eliminated during threshing) of wheat may reach 15 stooks (180 sheaths) per hectare in cases of severe disease (according to the technical organisation dealing with cereals in France), or 50-60\% [1,6,7,30] about once every three to five years $[6,16]$. In 2000, the year with the highest levels of disease in the last ten years, up to $100 \%$ of ears were affected on certain French plots [31]. There is a non-linear relationship between the percentage of ears attacked by $M$. nivale and thousand-grain weight [19,32]. Head blight also decreases the nutritive and technological quality of the grains (degradation of proteins, baking quality, nutritive value etc.).

Since the 1990's, interest in food health and safety has increased. For cereal products, one of the most important elements of alimentary risk is the possibility of mycotoxin accumulation on or in the grains [33-35]. Mycotoxins are the products of fungal secondary metabolism [34,36], which occurs when growth stops altogether or slows markedly [37]. These toxins result from adaptation of the growth of the fungus to stressful situations [37]. Head blight is the principal means by which mycotoxins develop in the grains before harvest. The mycotoxins produced in crops suffering from head blight are produced by fungi of the genus 
the mycotoxins produced by Fusarium cannot be reduced after harvest by means of classical transformation procedures [38]. These toxins are chemically and thermally stable $[39,40]$. They may therefore be found in the raw material (grains) and in transformed products (flour, bread) or in products from animals fed with contaminated grain (meat, milk, eggs) [35].

Mycotoxins cause two types of problem. They may generate technological problems, such as negative effects on malting for beer (inhibition of enzyme synthesis) or on fermentation (inhibition of yeast growth), or even on the production of high-quality bread [38]. Indeed, $F$. graminearum modifies a protease that acts on gluten. Damage to this enzyme prevents the dough from retaining the gas produced during fermentation, resulting in heavier, less voluminous bread. Furthermore, F. graminearum also destroys starch grains, protein stores and cell walls $[6,41,42]$.

Mycotoxins may also cause poisoning incidents, the principal symptoms of which are nausea, lethargy, fatty and cancerous infiltrations and possibly even death [38,43]. Six main families of mycotoxins have been studied to date: aflatoxins (B1, B2 and M1), ochratoxin A, trichothecenes (T2 toxin, deoxynivalenol etc.), zearalenone and fumonisins. Fusarium produces toxins of the last three groups, which may attack the liver, the kidneys, the nervous system, the circulatory system, the endocrine system, the skin, the digestive tract and the blood [44]. These toxins are thought to be highly carcinogenic, although this assertion remains unproven in most cases. However, T2 toxin has been shown to be carcinogenic [44]. The absorption of trichothecenes has resulted in the poisoning of animals and humans in the United States, Canada, the Soviet Union (as it was at the time) and Japan [39]. The massive absorption of $\mathrm{T} 2$ toxin was responsible for toxic alimentary aleukia in several regions of the USSR between 1942 and 1947 [34,39]. Pigs are the animals most reactive to deoxynivalenol, whereas poultry seem to be particularly resistant. Effects on humans have been observed after the absorption of 300 to $8000 \mu \mathrm{g} / \mathrm{kg}$ deoxynivalenol in India [8]. This led the public authorities to establish norms fixing maximum deoxynivalenol levels in food destined for human consumption. The European Commission has proposed setting limits of $750 \mu \mathrm{g} / \mathrm{kg}$ (750 ppb) in cereals and $500 \mu \mathrm{g} / \mathrm{kg}$ in cereal-based products such as flour. A major problem in trichothecene toxicology is the current lack of knowledge concerning the risk of food contamination by several of these toxins at the same time, as Fusarium can produce a multitude of toxins simultaneously [34]. 


\section{Factors triggering attacks}

The climate is known to have an effect, and is said to be the principal factor affecting the development of head blight on oat in Norway [45]: humidity determines the severity and intensity of the disease whereas precipitation and total radiation determine inoculum levels (number of spores per ear) [46]. The climate plays a role at all stages of development of the fungus [47-49]. The climate during winter affects the survival of the fungus on crop residues: during mild periods of the winter, the fungus is capable of sporulating on the cereal stubble debris [48]. In spring, the climate determines the type and quality of spores produced, together with the date of their dispersal and thus the intensity of the disease. Indeed, coincidence in the dates of spore dispersal and crop flowering, marking the start of the critical phase of infection for plants [2,6,16,50], is of prime importance in determining the intensity of the attack. In summer, together with the virulence characteristics of the fungal strain and the intrinsic resistance of the plant, climate controls competition between pathogen species, thereby controlling the rate of mycelium growth in the plant [47]. The climate may also affect the production of fungal toxins in the field [2,51-54]. The effects of climate are such that the levels of deoxynivalenol recorded on diseased crops in the field and in the glasshouse are not correlated [49]. The effects of climate are of course uncontrollable, but also difficult to predict due to their complexity.

However, in any given year, two neighbouring plots may display different levels of infection $[19,55]$. It must therefore be possible, to some extent, to control the production of mycotoxins by modifying the cropping system.

The literature review below aims to identify and to elucidate the relationships linking cropping systems to grain contamination by Fusarium, Microdochium or to mycotoxin production by Fusarium.

\section{1- Epidemiological study of the disease}

\section{1-1. Impact of climate on the species complex}

The species of fungi making up the pathogenic complex responsible for head blight may differ from year to year and from one region to another, particularly as a function of climate $[6,11,56]$ and wheat variety $[56,57]$. Indeed, climate partly controls competition between the 
various species. Thus, at flowering, the development of Microdochium is favoured by lower temperatures [6,58] and rainfall [59], whereas that of Fusarium is favoured by high temperatures [58] and storms [59]. F. graminearum is generally the predominant Fusarium species in warmer regions, whereas the predominant species in cooler regions are $F$. culmorum [6,16,28,60], F. avenaceum [6] and M. nivale [6,16]. Furthermore, in spring (before ear emergence), drought favours the development of symptoms of $F$. graminearum and F. culmorum infection at the base of the plant, at the expense of other species of Fusarium [59].

\section{1-2. Sources of inoculum}

145 Several reservoirs of the parasite complex responsible for head blight are known. The primary 146 reservoir of inoculum is debris from the previous crop [2,61]. All species of Fusarium and 147 Microdochium can survive as saprophytes [6]. However, the pathogens survive longer on 148 residues that do not degrade easily, such as stem nodes [2].

150 Other sources of inoculum include numerous plant hosts. These may be cultivated plants and/or weeds, such as grasses and evergreen weeds [6]. However, the roles of weeds, inoculum source (site at which the fungi develop) and supports for survival have not yet been determined [62]. Seeds are the other major source of inoculum, making it possible for the disease to begin in autumn in the case of grains contaminated with mycelium $[14,16]$. The further into the grain the mycelium has penetrated, the lower is the chance of the grain germinating. The soil may also be contaminated [1,2]. Soil-borne infections take hold less rapidly than seed-borne infections, resulting attacks affecting essentially the collar and the upper parts of the roots [2,14]. Soil humidity, particularly during winter, decreases the pathogen survival rate [2].

The flag leaf is the principal site of spore production and source of ear infection in the plant 162 [32].

\section{1-3. Production and maturation of inoculum}

165 During the winter, the fungi survive as chlamydospores, mycelium or propagules [2,6]. 166 Sporulation, which involves the production of various types of spore, occurs during mild 167 periods [48]. Four types of asexual inoculum may be produced, depending on the species 168 concerned: macroconidia, microconidia, chlamydospores and hyphal fragments, the size and 
form of which depend on the species of pathogen [63]. The macroconidia of $F$. graminearum may contain one to seven septa - most frequently three to seven - and measure 20 to 105 $\mu \mathrm{m}$ in length (mostly 35-62 $\mu \mathrm{m}$ ), and 2 to $56 \mu \mathrm{m}$ in width [2]. This type of inoculum may be available during the entire crop cycle [16]. Sexual spores, known as ascospores, may also be produced by reproductive organs called perithecia. Only three of the species most frequently responsible for head blight appear to be capable of producing ascospores in the natural state: M. nivale, $F$. graminearum and $F$. avenaceum [6,16,64]. These three species produce ascospores that are similar in size and form. They generally have three septa and measure about $17.5-26 \mu \mathrm{m} \times 3.5-5 \mu \mathrm{m}$ [2]. They take a long time to mature and therefore contamination cannot occur before ear emergence [16]. Caron reported that M. nivale produces ascospores from May onwards in France and that $F$. graminearum produces its ascospores later in the year.

In the laboratory, the optimal environmental conditions for production of the principal forms of inoculum - macroconidia and ascospores - depend on the species and the environment. These results probably cannot be directly transposed to natural conditions. Table 1 sums up the principal results reported in the literature.

The maturation of the inoculum has been studied in less detail and depends on interactions between environmental factors, both in the laboratory and in the field. The maturation of the inoculum is thought to be hindered by drought and cold in autumn and winter [65]. In the laboratory, perithecia have been reported to mature in six to nine days [66], or nine to ten days [2] after their initiation in ideal conditions. In contrast, perithecium maturation takes two to three weeks in the field whereas conidiospores can be produced in large quantities within a few hours [59]. According to another study, macroconidia reach maturity in three weeks in the field [67]. The rate of maturation of perithecia depends on light $[66,68]$.

\section{1-4. Dispersal of the inoculum}

The inoculum is dispersed by various animal vectors. Mites (Siteroptes graminum) transport F. poae spores [6]. Insects are parasitised by certain species of Fusarium, F. episphaeria (SN. and $\mathrm{H}$ ) in particular [63]. F. avenaceum, F. culmorum and F. poae have been isolated on various insects including Musca domestica (housefly), Hypera punctata (clover leaf weevil) and Melanoplus bivittatus [69]. 
204 The possibility of inoculum dispersal by the systemic route has long been debated; after 205 cutting the peduncle of a wheat ear into segments, Atanasoff (1920)[1] observed $F$. 206 graminearum in the segments close to the ear but not in those close to the flag leaf. Following 207 inoculation of the base of the wheat stem, only $3 \%$ of plants display colonisation beyond the 208 second node and no fungus is detected beyond the fifth node [70]. In another study [71], the 209 tops of plants produced from seeds inoculated with $M$. nivale presented similar numbers of 210 perithecia to those of plants grown from healthy seeds, even though the plants grown from 211 contaminated seeds had more perithecia at the base of the stem. This finding confirms the lack 212 of relationship between head blight and foot rot due to Fusarium [6,16]. To date, these two 213 infections have been considered to be essentially independent $[1,16]$. However, it should be 214 noted that the presence of the parasite at the base of the stem (below the second node) may 215 disturb the water supply to the ear sufficiently to cause shrivelling at the slightest increase in 216 temperature [14]. Shrivelling of part of the ear is one of the symptoms of head blight. A 217 confusion of symptoms is possible: in some cases, shrivelling of the ears may be due to the 218 presence of the parasite at the base of the stem rather than on the ears. In addition, following 219 the artificial inoculation of spring wheat seeds, sown in pots, with $F$. culmorum, the pathogen 220 is isolated from all nodes and from the ears [72]. Similarly, Snijders (1990a)[73] observed the 221 pathogen in stem tissue $70 \mathrm{~cm}$ above soil level after inoculating plants at soil level. Many 222 cases of infection with various species of Fusarium have been observed after the sterilisation 223 of weeds [62] and wheat [74] with sodium hypochlorite, which suggests that these infestations 224 are endophytic. Evidence that this is indeed the case is provided by the observation that the 225 fungal mycelium is capable of infecting both the parenchyma and the vascular tissue, in 226 which it is able to travel more rapidly [50]. Indeed, after the injection of spores into the rachis, 227 these authors showed that the pathogen was able to migrate within the plant and that it 228 propagated more rapidly longitudinally than transversely. However, it is possible that this 229 route of contamination is only possible in a few species of plant, for a few species of fungus 230 or for a few plant-fungus interactions.

232 Dispersal by leaf-to-leaf contact also seems likely as the pathogens (Microdochium and 233 Fusarium) are found on the leaves [15]. Atanasoff (1920)[1] also observed infection by 234 contact. This mode of dispersal should be considered to be a specific case of aerial contamination. 
Aerial contamination by ascospores and conidia is thought to be the principal source of ear contamination [1]. This means of contamination has been studied by many groups and involves two possible modes of dispersal: splashing and wind [2,6,7,16,64]. The relative importance of these two modes of dispersal depends on the climate and the species making up the pathogenic complex in the year and region studied and the capacity of these species to produce ascospores.

Splashing transports spores, macroconidia in particular, that are too heavy to be transported by wind [35]. The density of $F$. graminearum macroconidia in the air above the canopy has been estimated to be only one twentieth that of ascospores from the same species [75].

Splashing is the only means of dispersal of M. nivale conidia [71]. Millar and Colhoun were able to trap conidia only during simulated rain conditions, whereas Fernando et al. (2000)[75] observed a peak in the release of macroconidia of $F$. graminearum in the air one to two days after rainfall following a long period of drought. These two studies demonstrate the major role played by rainfall in the dispersal of spores. In the laboratory, a conidium of $F$. graminearum, produced in a sporodochium (the asexual fruiting body bearing the conidiophores) from wheat straw, receiving a single drop of water $5 \mathrm{~mm}$ in diameter falling from a height of $6 \mathrm{~m}$, was displaced by up to $45 \mathrm{~cm}$ in the vertical plane and $90 \mathrm{~cm}$ in the horizontal plane [17]. In the same conditions, a conidium of $F$. culmorum was displaced $60 \mathrm{~cm}$ vertically and at least $1 \mathrm{~m}$ horizontally [17,76]. The spores of $F$. poae may reach a height of $58 \mathrm{~cm}$ and may travel 70 $\mathrm{cm}$ horizontally in rebounding raindrops [76]. Splashing alone is therefore sufficient to transfer a conidium from crop residues or the stem base to the ear (in one or several rebounds, relayed by the leaves), assuming there is no obstacle. In the canopy, the leaves of the neighbouring plants form an obstacle. Under simulated rainfall, the wheat canopy reduces the dispersal of Septoria tritici spores by $33 \%$, to $15 \mathrm{~cm}$, in the horizontal plane from the source of infection, and by $63 \%$ in the vertical plane [77]. A leaf positioned low in the canopy is principally infected at its base whereas leaves higher up in the canopy are principally affected at their tips, from which the spore can rebound, resulting in their transfer to another leaf [76]. Splashing is considered to be the most likely means of dispersal because $F$. avenaceum, $F$. culmorum and $M$. nivale have been observed on the flag leaf [15]. Rainfall plays an important role in the development of the disease. In years with major epidemics of head blight or rotting of the ear due to $F$. graminearum, precipitation levels are generally high $[2,7,15,78]$. 
irrigated controls [6]. Furthermore, humidity and rainfall in spring favour the formation of perithecia [59].

In natural conditions, perithecia are formed in only the three species that generate ascospores: $F$. graminearum, $F$. avenaceum and $M$. nivale [6,16,64]. Ascospores are a form of inoculum that can be transported by the wind $[6,16]$. The wind has long been considered the principal vector for spore dispersal, and damage tends to be greatest in the direction of the prevailing wind [1]. Following the artificial inoculation of a zone of field with maize grains infected with $F$. graminearum, $F$. graminearum spores travel less than $5 \mathrm{~m}$ [75]. However, Stack (1997)[79] indicated that the dispersal distance of $F$. graminearum spores is proportional to the size of the area inoculated. According to this model, head blight levels halve as the distance to be travelled by the inoculum doubles. The maximum density of ascospores observed is 1500 spores $/ \mathrm{m}^{2}$, at $1.5 \mathrm{~m}$ from the source of inoculum [75]. The dispersal of $F$. graminearum ascospores in the field occurs at temperatures of 13 to $22{ }^{\circ} \mathrm{C}$, with a relative humidity of 95 to $100 \%$ [2]. Ascospore release is maximal at a relative humidity of $100 \%$, but also occurs at lower levels of relative humidity [66].

Despite the importance of humidity, studies on $F$. monoliforme $[67,80]$ and $F$. graminearum [75] have shown that the release of ascospores is not directly linked to rainfall. Indeed, ascospore release peaks one to four days after rainfall $[67,75]$ of at least $5 \mathrm{~mm}$ or a relative humidity exceeding 80\% [67]. Paulitz found that a shower of rain in the evening did not inhibit spore release but that heavier rain (at least $5 \mathrm{~mm}$ ), a relative humidity exceeding $80 \%$ continuously throughout the day or the alternation of rain and high humidity inhibited the release of ascospores during the night. This result contrasts with another study showing the release of ascospores during the night following a day on which $8 \mathrm{~mm}$ of rain fell [81]. The correlation between spore release and humidity suggests that the maturation of perithecia requires a certain level of humidity. This would account for the results of Fernando et al. (2000)[75], who observed four periods of spore release over a period of 20 to 30 days.

\section{The process of ascospore release may be described as follows [71]: after a period of drought} (air with low water vapour content), free water (rain or heavy dew) triggers the release of ascospores. Paulitz (1996)[67] speculated that the increase in relative humidity during the evening after a dry day might increase the turgor pressure of the asci, which contain a vacuole at high osmotic pressure [82]. This high osmotic pressure is generated by the accumulation of 
mannitol and the flux of potassium and calcium ions [66]. Calcium ions are also involved in signalling for ascospore discharge [66]. This increase in pressure triggers the release of ascospores, which are expelled from the perithecia in a gelatinous substance, which then dries out, releasing the ascospores into dry air. This would account for the finding that a trap placed above the canopy captures several $M$. nivale ascospores in dry conditions and that the concentration of these spores increases by a factor of 20 in the 10 minutes following the application of a fine simulated dew [71]. A similar phenomenon has also been observed for the ascospores of $F$. graminearum [6]. Similarly, in control conditions, the maximal release of $F$. graminearum ascospores is regulated by dehydration of the perithecia in non-saturated humidity conditions [83]. Furthermore, the time at which the spores are released is strongly correlated with the increase in humidity following the decrease in temperature that occurs at the end of the afternoon [67]. Paulitz observed that ascospore release began before the leaves became humid at the base of the canopy (which occurred at 22-24 h), towards 17 or $18 \mathrm{~h}$ for temperatures varying between 11 and $30{ }^{\circ} \mathrm{C}$ and values of relative humidity of between 60 and $95 \%$. These results have been confirmed by the observation, in control conditions, that the maximal release of $F$. graminearum spores occurs at temperatures between 11 and $23{ }^{\circ} \mathrm{C}$, with $16{ }^{\circ} \mathrm{C}$ the optimal temperature [83].

After temperature and humidity, the next most important environmental factor affecting ascospore release is light. Light is required for the production and maturation of perithecia [68] and ascospores [83]. In contrast, the process of ascospore release does not directly require light, as it has been observed during the night: 4 to $5 \mathrm{~h}$ before sunrise [67]. This result has been corroborated by studies in control conditions, which also showed that light had no effect on ascospore release [66,68].

Finally, the periodicity of aerial dispersion has been studied. The release of conidia is not periodic, whereas that of ascospores is, particularly in F. graminearum [75]. Indeed, Fernando et al. detected no ascospores in the air between 12 and $16 \mathrm{~h}$, whereas ascospore density was maximal between $20 \mathrm{~h}$ and $08 \mathrm{~h}$ (1.5 times higher than at other periods of the day). Other authors have reported that ascospore density peaks between $21 \mathrm{~h}$ and $08 \mathrm{~h}$ [84]. Similarly, Paulitz reported that spore release often occurs between $18 \mathrm{~h}$ and early morning $(04 \mathrm{~h}-08 \mathrm{~h})$, mostly before midnight, with a peak at around 23 h [67]. For F. graminearum, the maximum ascospore concentration observed is of the order of 4333 ascospores $/ \mathrm{mm}^{3}$ in one hour. Paulitz 
with densities varying according to the period of the day. Paulitz identified four distinct periods in the day, and found that spore density was low in the morning. For $F$. monoliforme, a large number of ascospores was found to be released between $17 \mathrm{~h}$ and $08 \mathrm{~h}$, with a peak towards $02 \mathrm{~h}[80]$.

Although dispersal over large distances seems to be possible, local aerial contamination appears to predominate, in that two neighbouring plots of land planted with the same variety may display very different levels of contamination $[19,55]$.

\section{1-5. Infection and colonisation of the ear}

In wheat, the most critical period corresponds to the moment at which the degree of resistance to primary infection and to the propagation of fungal hyphae in the plant is lowest. This period has been defined differently by different authors, but the first half of the grain-filling period is the most critical. Several authors have identified ear emergence $[64,85]$ or the midgrain-filling stage [47] as the most critical, but most authors consider anthesis to be the most susceptible to attack in wheat $[12,16,64,86,87]$, with susceptibility decreasing strongly after the start of the dough stage $[12,16,47,64,86,87]$. Elimination of the male organs from wheat ears decreases the frequency of infection by $F$. graminearum $[47,86]$. Similarly, sterile wheat lines are less susceptible to head blight than fertile lines [88]. This, together with extensive colonisation of the anthers by this fungus [86] indicates that the growth of $F$. graminearum is stimulated in these structures, suggesting that entry into the anthers during anthesis has major consequences for the grain (degradation). Two substances - choline chloride and betaine hydrochloride - are much more concentrated in the anthers than elsewhere [89]. These substances favour the extension of conidial hyphae, but not the germination of spores of $F$. avenaceum, F. culmorum and F. graminacearum [89]. Once the spores have germinated, the propagation of the hyphae is therefore more strongly favoured in the flower parts than in the other organs. However, the difference in susceptibility of different stages is probably due to the fact that the critical receptivity peak observed (degree of resistance to primary infection and propagation of fungal hyphae) is dependent on many factors. These factors include the wheat cultivar $[12,47,50,90]$, air temperature and humidity $[12,47]$ at the critical stage for the plant and, before this stage, development of the inoculum, and the stage of maturity of the plant at the time of hyphal penetration [12]. The testa (seed coat) is more resistant to penetration when the grains are mature [12]. However, this finding remains open to debate because a recent study [91] showed that the date of inoculation has no effect on the final level 
of $F$. graminearum colonisation. In maize, susceptibility to the disease is maximal at the start of silk development and decreases throughout the grain-filling period [92]. In Arabidopsis thaliana, tobacco, tomato and soybean, the floral tissues are also the most heavily infected [93].

The infection process is very similar in susceptible and resistant varieties [94]. The pathogen first penetrates host tissues 36 to $48 \mathrm{~h}$ after inoculation [94]. The first organs affected are the lemmae and the tip of the ovary [94,95], the anthers [12] and/or the spikelets, glumes and the rachis [50]. It remains unclear which of these organs is most frequently the initial zone infected, but this probably depends on the date of infection and possibly also on the infecting species. The penetration of the fungus into the ear is favoured by relatively low temperatures and high humidity [64]. The presence of and colonisation by a large number of hyphae are required for infection [50]. The hyphae of $F$. graminearum and/or $F$. culmorum invade the host tissue directly [94] or via the stomata [50]. They then propagate into the ear, passing through and around the cells in their path [12,94-96], degrading the cells that they contaminate $[50,94,96]$. They move principally towards the rachis $[94,95]$ or towards the young grains, which they invade via the parenchyma of the pericarp close to the embryo [50]. A short time after flowering, the parenchyma of the pericarp begins to break down, the nuclei and cytoplasm of the cells disappear and the walls of the cell break [12]. F. graminearum is then able to enter this tissue and propagate throughout the grain [12]. Indeed, $F$. graminearum hyphae penetrate the thinner cell walls of the parenchyma tissue more easily than the thicker cell walls of other more specialised tissues [12]. Birds also facilitate infection by creating lesions on the grains that favour the penetration of fungi [2].

Infection of the ears by macroconidia of $F$. graminearum [47], F. avenaceum, F. culmorum, F. poae and M. nivale [6] is optimal at $100 \%$ relative humidity and $25{ }^{\circ} \mathrm{C}$, and takes place over 24 to 60 hours. Infection may occur at temperatures of 20 to $30^{\circ} \mathrm{C}$, but is negligible at temperatures below $15{ }^{\circ} \mathrm{C}$ [47]. Below $18{ }^{\circ} \mathrm{C}$, the conidia of M. nivale are more competitive than those of Fusarium, resulting in higher levels of $M$. nivale contamination. Furthermore, a period of four to eight days of low humidity reduces the incidence of infection, but does not entirely eliminate it [47]. The germination of macroconidia, ascospores and chlamydospores is maximal between 0 and -20 bars and is inhibited between -60 and -80 bars [97]. Ascospore germination is inhibited beyond a threshold of -30 bars $(-3 \mathrm{MPa})$ of water 
406

407

408

409

410

411

412

413

414

415

416

417

418

419

420

421

422

423

424

425

426

427

428

429

430

431

432

433

434

435

436

437

438

potential after eight hours of drought [67]. Free water or a low water potential also favours infection, reducing the length of the incubation period [67].

\section{1-6. Incubation and sporulation}

Perithecia and conidia develop on the surface of spikelets and of the rachis in humid climatic conditions [2]. The duration of the incubation period required decreases with increasing humidity [16]. In conditions of saturating humidity, the duration of incubation required for the appearance of macroconidia of $F$. culmorum and $F$. graminearum on the ear was 12 days at $14{ }^{\circ} \mathrm{C}$, less than five days at $20^{\circ} \mathrm{C}$ and less than three days at between 25 and $30{ }^{\circ} \mathrm{C}[2,16]$. More spores are formed after a long period of high humidity. This may then result in the infection of later crops, such as maize.

\section{2- Effects of various cultural practices on the disease}

Various studies have identified different elements concerning the effects of agricultural practices (crop rotation, crop management) on head blight attacks.

\section{2-1. Effects of the crop succession history of the field}

The effects of crop rotation have been studied in detail. They depend on the preceding crop, whether that crop is a potential host for the pathogens responsible for head blight, and the frequency of the crop concerned in the rotation. The shorter the rotation, the higher the frequency of head blight. Thus, head blight is most frequent when the susceptible crop occurs frequently within the rotation [7]. The density of crop residues left in the field [19], their nutritional value [19] and pathogen competition may also modify the effect of crop rotation $[19,62]$.

Head blight contamination is more severe if the preceding crop is maize, durum wheat or oats, rather than wheat or barley [14,19,48,64,98-101], and even less contamination is observed following other crops $[16,48]$. For example, the frequency (\%necrotic ears) and the severity (\%necrotic spikelets) of the disease on wheat are lower following soybean than following another wheat crop, or worse still, maize [19]. This may be accounted for in two ways. Firstly, soybean crops leave fewer residues than wheat crops, which in turn leave fewer 
residues than maize crops $[7,19,100]$. Secondly, the principal Fusarium species infecting soybean is $F$. sporotrichioides, whereas wheat and maize are more frequently affected by $F$. graminearum [19], like sorghum [59]. Thus, in addition to the density of residues left by the preceding crop, the nature of the preceding crop is important in determining the pathogen species likely to infect the next crop in the rotation. The preceding crop affects the composition of the pathogen complex throughout the following year. Thus, a preceding crop of potato will allow the development of only $F$. culmorum and $F$. sambucinum, whereas a preceding wheat crop will allow the development of all Fusarium species [62]. It should also be noted that the highest levels of $F$. graminearum contamination are recorded on grains harvested from wheat crops following maize in the rotation, whereas $F$. avenaceum and $F$. poae are the most common species found in grain samples harvested from wheat crops following a crop other than maize [60]. It is therefore advisable to introduce non-host plants into crop rotations, to limit the disease [7]. Indeed, the use of oats as the preceding crop results in a doubling of head blight inoculum in the soil [64,98] even though this crop is unaffected by the disease [14] whereas a preceding crop of sugarbeet, which is hardly affected by Fusarium, halves the incidence of the disease in the subsequent wheat crop $[14,64,98]$. Similarly, flax can be used as a clean-up crop [16], as can alfalfa, after which no disease is observed [102]. However, the quantity of crop residues and the development of pathogens on the preceding crop are not the only explanations of the effect of preceding crop. Wheat crops present different levels of infection depending on whether they follow wheat or durum wheat in the rotation, even though these two preceding crops produce similar amounts of residues and are equally permissive for Fusarium development.

Among the other elements possibly involved, the amount of nitrogen in crop residues may affect the possible duration of colonisation by Fusarium. Indeed, the high nitrogen content of maize residues may result in a longer period of colonisation of those residues by the fungi, strengthening these fungal populations [2] and favouring disease.

It is also likely that proteolytic soil bacteria, favoured by the low carbon to nitrogen ratio under alfalfa, compete with Fusarium species, limiting their development and thus their ability to attack the subsequent crop [62,102]. It should also be noted that, at the end of the cropping cycle, buried cereal stubble provides an ideal substrate for saprophytes, increasing the carbon to nitrogen ratio, possibly resulting in the reappearance of the disease [98]. 


\section{2-2. Effects of soil tillage}

The effects of soil tillage are also well known, at least from a qualitative point of view. As for yellow and brown rusts [103], limited soil tillage increases the frequency of head blight $[7,19,100]$, whereas deep tillage (ploughing) decreases it [7,19,64,90,101]. Similarly, limited tillage systems increase the number of Fusarium propagules in the soil [14] whereas ploughing decreases inoculum levels [98].

This effect of ploughing may be accounted for in several ways. Ploughing has several direct and indirect effects on the structure [104,105] and microclimate of the soil $[105,106]$ and therefore on the development of fungi [105], notably those of the genus Fusarium. Limited tillage and direct drilling systems make it harder to deliver the seed to the required position during sowing, decrease soil porosity, increase structural stability and litter on the surface. The litter layer protects the soil from rain (battering and erosion), and increases surface humidity (by limiting evaporation), soil temperature and inertia. This layer breaks down into organic matter, enriching the surface soil in carbon and organic forms of nitrogen, and modifying its chemical and biological characteristics. Stores of inorganic carbon increase, the supply of soil mineral nitrogen decreases very slowly and the mineralisation process is delayed. The microbial biomass (bacteria and fungi) increases at the surface and its turnover rate increases in the first $10 \mathrm{~cm}$ of soil. Humus is thus less well degraded in this zone, which rapidly becomes more acidic, favouring the development of fungi over that of bacteria. Thus, about $90 \%$ of the Fusarium roseum population is located in the first $10 \mathrm{~cm}$ of soil [98]. Furthermore, the development of this fungus depends on soil aeration [14]. Although this pathogen can survive for four years [16] at a depth of 20 to $25 \mathrm{~cm}$, it is only active and able to develop on plant debris in the first $5 \mathrm{~cm}$ of soil [14]. Beyond a depth of $15 \mathrm{~cm}$, the incidence of Fusarium oxysporum attacks on carnation decreases as the depth of propagule burial increases [107]. However, this result cannot be readily transposed to other species because Microdochium nivale and Fusarium avenaceum do not produce chlamydospores [108] and the number of propagules in the soil does not necessarily affect Fusarium foot rot levels due to Fusarium culmorum [109]. Thus, for certain species, propagules may simply ensure the survival of the fungus rather than serving as an inoculum $[98,109]$.

The development of the Fusarium roseum population also depends on the quantity of substrate (crop residues) available [14]. Thus, a decrease in the density of residues on the surface of the soil (after ploughing for example) helps to decrease the production of inoculum 
$[100,110]$ and the quantity of spores available for dispersal [109]. This hypothesis seems to be validated by the observation that there are fewer Fusarium culmorum propagules if the stubble from the preceding crop is burnt than if it is buried [109]. However, an opposite effect on the disease is observed. Thus, in years in which there are high levels of Fusarium infection at the base of the stem, disease levels have been found to be higher if the stubble from the previous crop was burnt than if it was incorporated into the soil [109]. A similar result was previously reported for eyespot [111]. Similarly, the supplementary incorporation of infected stubble not originating from the preceding crop decreases the incidence of Fusarium attacks resulting in wheat foot rot to levels below those observed in soils in which the density of residues has not been modified [112]. However, these results may be explained if stubble limits conidium dispersal by splashing, favours growth of the canopy [111], or modifies the infection process. In Yarham's study [111], the addition of stubble did not affect leaf area index, photosynthetic potential or the number of leaves. It also resulted in no decrease in the density of wheat or weeds and had no effect on the size of the plants. All these factors might have facilitated spore dispersal. In the infectious process, four aspects may be affected by the presence or absence of stubble. Firstly, the resistance of the plants may be affected by increases in the amount of silica $\left(\mathrm{SiO}_{2}\right)$ in the leaves of the wheat plants following the incorporation of additional stubble [112]. The hypothesis that silicon plays a protective role arises from work [103] indicating that this element strengthens cell walls and, particularly, the outer membrane of epidermal cells, increasing resistance to the penetration of pathogen germination tubes in leaves containing large amounts of silicates (shown experimentally for the penetration of Erysiphe graminis, which causes powdery mildew on barley) [113]. Similarly, adding silicon decreases Fusarium infections and powdery mildew in cucumber [114]. All changes in the structure and microclimate of the soil, the date, method and depth of stubble incorporation also influence the extent and dynamics of crop residue decomposition [105], which may in turn affect head blight levels. Indeed, in optimal conditions of microorganism colonisation and water and nutrient exchange, the area of contact between the soil and crop residues (affected by the size of the residues and soil porosity) is maximal, accelerating residue decomposition [105]. Consequently, despite providing a larger source of inoculum, stubble incorporation increases the rate of degradation of crop residues, decreasing the duration of colonisation of these residues by pathogens such as Pseudocercosporella herpotrichoides [110]. These pathogens are thus less well developed, resulting in lower attack rates, which in turn results in slower spore maturation following changes in humidity, light 
541 decomposition of stubble results in the production of substances toxic to fungi or that favour

542 the microorganisms engaged in stubble decomposition, thereby creating competition between

543 microorganisms [111], limiting the production of spores. Finally, a study of Fusarium foot rot

544 showed that the distribution of crop residues is the primary factor influencing the site of 545 penetration of the fungi [115].

\section{2-3. Effects of irrigation}

548 The irrigation of a field influences its microclimate and may encourage the development of 549 the pathogen. Regardless of whether the climate is favourable for the disease in a given year, 550 irrigation increases the frequency (\% necrotic ears) and severity (\% necrotic spikelets) of the 551 disease over that in non-irrigated plots $[19,90]$.

553 Uncertainties concerning the survival of the fungus in the soil and its capacity to sporulate in 554 the soil as a function of soil aeration, porosity and light levels, together with the role played 555 by the rate of residue degradation and that of the compounds generated by this process, and 556 their mineral composition (nitrogen, silicon) limit our ability to make quantitative predictions 557 of the effects of the preceding crop, soil tillage or irrigation.

\section{2-4. Mineral nutrition}

560 The effects of mineral nutrition on head blight attacks are unclear. As nitrogen applications 561 favour the development of the plant, making the canopy more humid, it has often been 562 suggested that such applications are likely to favour the appearance of diseases $[103,116]$. 563 This has been demonstrated for bunt [103] and blotch or Septoria disease [117]. In fact, the 564 severity of Septoria attacks on wheat is increased by $11 \%$, which corresponds to a yield loss 565 of $8-9 \%$, following treatment with $100 \mathrm{~kg}$ of nitrogen per hectare [117]. Nitrogen application 566 significantly increases the incidence of Fusarium infection in grains of wheat, barley and 567 triticale $[118,119]$ and the predisposition of wheat to attacks by $F$. avenaceum and $M$. nivale 568 [116]. Similarly, mineral nitrogen applications increase the number of $F$. culmorum 569 propagules [108]. However, in a two-year study, Teich (1989)[90] showed that nitrogen 570 application limited the disease in the first year [99], although this decrease was not confirmed 571 in the second year [100]. Fauzi and Paulitz (1994)[120] also demonstrated that disease levels 572 were similar in the presence and absence of applications of $140 \mathrm{~kg} / \mathrm{ha}$ ammonium nitrate. 
574 There are two possible reasons for the uncertainties concerning the effect of nitrogen 575 applications on the disease. Firstly, in certain cases, the applied nitrogen may be poorly distributed in the soil. Fusarium foot rot levels have been shown to decrease if ammoniacal nitrogen is applied with a syringe to the tilled layer but not if it is mechanically applied to the field [121]. Secondly, there may be an as yet unidentified link between attacks of Fusarium foot rot and head blight [6]. Thus, nitrogen-containing fertilisers may have a different effect on the Fusarium head blight and thus affect the production of head blight inoculum. This link may involve competition between the species of Fusarium more specific to foot rot (such as $F$. solani) and those more specific to head blight (such as the species of the F. roseum group). Indeed, whereas germination of the conidia of $F$. solani is decreased by nitrate application, spores of the species of the F. roseum group use all forms of nitrogen [122].

Different forms of nitrogen have different effects. Urea appears to reduce head blight levels more than ammonium [90,123]. Teich (1989)[90] suggested three hypotheses to account for this difference between urea and ammonium: i) the urea may decrease the size of the Fusarium population because nitrite blocks reproduction in these fungi and inhibits the formation of chlamydospores [124], ii) urea may prevent the maturation of Fusarium ascospores, as it does for those of Venturia inequalis [125], iii) urea may increase the number of actinomycetes in the soil [122,126], these microbes being antagonists of Fusarium graminearum [126] and $F$. oxysporum [122]. Furthermore, rotting of the base of the stem and of the roots is more severe if nitrogen is applied in an ammoniacal form than as nitrate $[121,122,127]$. This may also result from the higher rate of germination of $F$. solani (which may cause foot rot) in the presence of ammoniacal nitrogen than in the presence of nitrate [122].

In contrast to what was observed for bunt [103], the application of phosphorus has been shown to limit foot rot [128] and head blight [99]. However, the result obtained for head blight was not confirmed in the second year of the study [100].

602

603 Potassium application decreases transpiration by causing stomatal closure, thereby helping to decrease the humidity of the air. Thus, the application of potassium limits the germination of rust spores [103]. Furthermore, high levels of potassium favour the synthesis of highmolecular weight compounds (such as cellulose), decreasing the availability of nutrients to 
607 the pathogens and increasing mechanical resistance to parasite penetration [103]. However, 608 potassium applications do not appear to affect the incidence of head blight [100].

610 To understand the meaning of these contradictory results, we need to bear in mind that the 611 effect of fertiliser applications depends on two factors: the age of the plant and the balance of 612 mineral elements. Indeed, foot rot levels are decreased by early applications of nitrate but 613 increased by late nitrate applications [128]. Conversely, foot rot levels are increased by early 614 potassium applications and decreased by late potassium applications [128]. Moreover, the 615 application of manures with a poor nutrient balance leads to more severe foot rot symptoms 616 [14,64]. Antagonism between nitrogen and potassium is generally reported [14,103]: excess 617 potassium and nitrogen deficiency render the plant more resistant whereas potassium 618 deficiency and excess nitrogen render it more susceptible. This antagonism results from the 619 fact that potassium increases nitrate absorption [122]. The nitrate absorbed activates nitrate 620 reductase, leading to the accumulation of amino acids [127]. These amino acids are used in 621 the synthesis of organic nitrogenous compounds [122] and of high-molecular weight compounds [103]. These compounds, like cellulose, contribute to the resistance of plants to diseases by increasing mechanical resistance to parasite penetration and by decreasing the quantities of soluble amino acids and low-molecular weight carbohydrates, which serve as nutrients for these pathogens [103]. Soluble amino acids and low-molecular weight carbohydrates are produced by increasing the activation of nitrate reductase in the presence of excess nitrate, by activating enzymes such as amylase, proteases and glucosidases, and by decreasing phosphorylation in conditions of potassium deficiency [103]. This increases the intracellular concentration of these compounds [103], favouring the development of pathogens.

Maize plants are most resistant to diseases when sugar concentrations are high [129]. Sugar

633 levels are inversely proportional to nitrogen supply and directly proportional to potassium 634 supply [14]. Conversely, if we consider three, rather than two, mineral elements, the mineral 635 balance least favourable for the development of foot rot in wheat, both in seedlings and in 636 adult plants, is high levels of nitrogen and potassium and low levels of phosphorus [128].

638 Several studies have demonstrated the existence of a relationship between the mineral and 639 organic composition of the soil and the development of soil microorganisms, which may 640 antagonise or stimulate the development of Fusarium. Thus, applications of organic fertiliser 
641 rich in nitrogen, particularly the ammoniacal and nitrous acid forms, significantly reduce (by

642 a factor of 1000) the size of the populations of many soil pathogens and markedly increase the 643 size of populations of soil microorganisms [123]. Furthermore, a mixture of ammoniacal 644 nitrogen and ammonium is recommended to increase the capacities of Pseudomonas 645 fluorescens populations, thereby favouring the development of the plant (as this bacterium is a 646 rhizobial bacterium) and inhibiting the development of Fusarium [130]. An application of 647 glucose (simulating root exudates) to soils containing chlamydospores of $F$. oxysporum and $F$. 648 solani favours the germination of these spores and the development of their germination tubes 649 [131]. A similar result was also reported in a previous study: wheat root exudates increase the 650 number and length of germination tubes arising from the spores of $F$. roseum and $M$. nivale 651 [98]. The effect of glucose application is even greater if the soil is nutrient-poor, especially for 652 slow-growing species such as those of the genus Fusarium [132].

654 The mineral nutrition of plants and the development of microorganisms in the soil also 655 depend on soil $\mathrm{pH}$. The conidia of $M$. nivale do not germinate in culture in vitro if the $\mathrm{pH}$ of 656 the medium is lower than about 5 [11]. However, $\mathrm{pH}$ has been found not to affect the incidence of the disease $[99,100]$.

\section{2-5. The effect of sowing date}

660 Sowing date is another element of crop management that has an indirect effect on the 661 production of, and infection by spores, because it partly determines flowering date, together 662 with the variety sown and climate. If the sowing date is such that flowering coincides with spore release, then more frequent and severe attacks are likely. This hypothesis is based on the fact that the anthesis is the stage in wheat at which the consequences of pathogen attack are thought to be the most severe [12,16,86,87].

666 The effect of sowing date should therefore be considered with respect to the level of attack as 667 a function of the earliness of the variety. Early-maturing wheat cultivars tend to be more resistant to head blight than cultivars that mature later [133]. The duration of the growth period in wheat has a significant positive effect: the longer the cycle of the variety, the lower the degree of contamination observed [134]. As this effect is not observed in barley and oats, Couture [134] suggested that the threshold number of days exceeds the length of the cycle for wheat, but not for barley and oats. However, conflicting results were obtained in other studies: resistance to head blight has been shown to be independent of maturity factors [135], and late sowing has been shown to favour the development of head blight whereas early 
sowing favoured the development of foot rot [16]. The results obtained almost certainly depend on the climate of the region concerned and the variety grown. Flowering period and the duration of the growth period for a given variety probably depend essentially on the year and region concerned: the only valid way to determine the characteristics (period and duration of flowering and growth duration) of varieties adapted to a given region is to carry out a frequency analysis of the climate, which requires the monitoring of head blight attacks in a given region over many years. Sowing on several dates (to extend the flowering period) should make it possible to limit the risk of heavy contamination in all the fields. A frequency analysis in a given region may also provide useful information for the optimal choice of sowing date.

\section{2-6. Effects of canopy density}

If the inoculum is dispersed primarily by splashing, the density of the canopy is an important factor as it may place obstacles in the way of this dispersal. Thus, a low canopy density can favour spore dispersal (by creating fewer obstacles). In the case of high canopy density, due to nitrogen fertilisation and/or higher sowing density and/or smaller spaces between rows of wheat, two opposing effects may be observed. Firstly, the high density is likely to increase the humidity of the canopy [116], favouring spore germination, as has been observed for rusts [103]. Alternatively, the high density of the canopy may increase the number of obstacles, limiting the vertical dispersal of spores towards the ear. However, for Fusarium infections, more severe attacks of foot rot [16] and head blight [5] have been reported in cases of high population density: more than 350 grains sown per $\mathrm{m}^{2}$ [16].

Plant population density may also be increased by weed infestations. In the presence of a large weed population, the number of species of Fusarium causing head blight in wheat increases, as does the intensity of the disease [1]. This may be accounted for by the number of common field weeds (both dicotyledonous and monocotyledonous weeds) on which numerous species of Fusarium have been detected [62]. Table 2 lists the various weeds known to serve as hosts for Fusarium, and the species of Fusarium found on them.

The "host-plant" nature of these weeds $[14,48,62,98]$ suggests that they constitute a potential source of inoculum. Since 1950, grass weeds have been suspected to act as a source of 
inoculum whereas other weeds have been thought to favour infection in a different way, by modifying the microclimate, increasing heat and humidity [136].

Whatever the role played by the various weed families, the decrease in the incidence of the disease following the use of herbicides suggests that weeds do have an effect [99]. However, different results were obtained in the following year of the same experiment [100]. This difference probably results from interactions between cultural practices and weeds. For example, the withering of forage grasses (fescue, cocksfoot, ryegrass) due to $F$. roseum increases with the dose of nitrogen applied [14].

\section{2-7. Effects of infestation of the canopy by bioaggressors others than fungi responsible} for the head blight

The term "canopy" is often used to describe the green canopy, consisting of healthy plants. Diseases, particularly foliar diseases, decrease the area of the plants capturing light, thereby limiting the development of the crop. Very few studies have focused on the competition between pathogens or between diseases. Only two authors have analysed the effect of a powdery mildew attack on head blight, and the results of these two studies conflicted. In the first study, powdery mildew attacks were found to have a positive effect on head blight attacks [30] whereas in the second, no effect was observed [99]. These conflicting results may be accounted for by several factors, such as climatic conditions, the varieties cultivated and the intensity of the diseases in these studies.

In addition to soil microorganisms (discussed in section 2-2), the ear microorganisms play a role, notably in biological control [137]. Indeed, the plant may be protected against pathogen attacks by prior inoculation with pathogen isolates of various degrees of virulence, which is

733 known to induce resistance in cases in which protection requires activation of the host's 734 defence responses [138]. Thus, inoculation with Microsphaeropsis spp. significantly decreases the production of $F$. graminearum ascopspores on wheat and maize ears and, to a lesser extent, on wheat and maize residues [137,139]. This decrease is particularly large if the residues are inoculated early with Microsphaeropsis (test with inoculation two weeks before the F. graminearum attack and 4 to 6 weeks after it) [137]. Prior inoculation with Phoma betae or Pythium ultimum decreases the severity of head blight on wheat and extends the incubation and latent periods of the disease due to F. culmorum, F. avenaceum, F. poae and 
ear and decreases the number of Fusarium isolates obtained from the harvested grains [138].

743 A previous study [140] showed that contact between Pythium oligandrum and F. culmorum macroconidia led to coagulation and a loss of cytoplasm, followed by complete degradation of the walls of the macroconidia and the production of Pythium oligandrum oogonia in abundance on the parasitised macroconidia. Inoculation of wheat ears with Alternaria alternata, Botrytis cinerea or Cladosporium herbarum at GS69 (Zadoks growth scale, Zadoks et al.,1974[141]) favours the infection of ears inoculated with F. culmorum at GS65, whereas prior inoculation, at GS59, decreases infection of the ears by F. culmorum [142]. Following the demonstration of antagonism between these saprophytes, Liggitt et al. [142] suggested that Alternaria alternata, Botrytis cinerea and Cladosporium herbarum produce volatile antibiotic substances that limit the growth of F. culmorum, consistent with the decrease in size of $F$. culmorum colonies observed following prior inoculation with other saprophytes.

Such antagonism is also observed between Fusarium species [22,27] and between species of Fusarium and Microdochium [22]. This is the case, in particular, for fungicide treatments acting against only one of these genera, resulting in the development of the unaffected genus to a greater extent than in the absence of treatment, when the two genera compete $[21,22]$. Similarly, prior inoculation with germination fluid from $F$. avenaceum predisposes wheat ears to infection by conidia of $F$. avenaceum or M. nivale, but not by conidia of $F$. culmorum, or $F$. poae. Other germination fluids were found to have no such effect [138]. This suggests that diffuse substances present in the germination fluid of $F$. avenaceum promote the production in competitive host tissues of resistance factors specific for $F$. avenaceum and $M$. nivale [138].

\section{2-8. Effects of chemical treatments}

The efficacy of fungicide treatments for head blight is variable, and difficult to predict. It depends not only on the active ingredient but also on the method and date of application of the fungicide [6,27]. If a fungicide treatment is to be effective, it must be applied several days before the attack and entirely cover all the ears [142]. Efficacy also depends on the interaction between fungal development and climate [143], the virulence of the pathogenic strains [143] and above all, the parasite complex present on the plot of land concerned [6]. Each of the fungal species implicated in head blight has a specific fungicide susceptibility profile: $F$. graminearum is particularly susceptible to triazoles whereas $F$. avenaceum is more susceptible to strobilurins. F. roseum, a complex consisting of F. graminearum, F. culmorum and $F$. avenaceum, is much more susceptible to triazoles than is $M$. nivale, which is 
essentially susceptible to strobilurins [22]. Triazole fungicides containing tebuconazole are currently the most effective $[21,27,143]$.

Chemical treatments may have an effect by modifying the height of the canopy. For a single variety grown in a single year, in a single region, the use of plant growth regulators (primarily gibberellin inhibitors) results in more severe head blight attacks $[14,64,118,120]$. This is presumably because plant growth regulator treatment results in the ears being closer to the soil, and therefore to the crop residues (source of inoculum), facilitating the dispersal of the spores to the ear (by splashing in particular). Indeed, the distance of the ear from the soil is a factor for resistance by avoidance in cultivars. Plant growth regulators also affect the microclimate of the crop residues on the soil [120], possibly increasing the production of perithecia and ascospores.

\section{3- Effects of various cultural practices on the production of mycotoxins by} Fusarium

The effects of cultural practices on the intensity and severity of head blight symptoms are well documented, at least for certain practices, but far fewer studies have considered the effects of these practices on mycotoxin production.

\section{3-1. Mycotoxins produced by Fusarium}

Fungi of the genus Microdochium are currently considered not to produce toxins [8] and will therefore not be dealt with in this section. It should also be noted that studies on the mycotoxins produced by Fusarium have generally focused on deoxynivalenol (DON), even though Fusarium also produces other types of mycotoxin. Figure 2 presents the chemical structures of the main mycotoxins produced by Fusarium.

Deoxynivalenol belongs to the trichothecene family, which contains two types of toxin: type A and type B. Type A toxins include toxins T2, HT2, diacetoxy-scirpenol (DAS) and scirpenol [39], which act on the initiation of protein elongation [144]. Type B corresponds to deoxynivalenol (DON or vomitoxin) and its acetyl derivatives - 3-acetyldeoxynivalenol (3acDON) and 14-O-acetylDON-4 - nivalenol (NIV) and verrucarol [39]. The toxins of this group act on the elongation and termination steps of protein synthesis [144]. Trichothecenes are toxic to all organisms. In mammals, the absorption of trichothecenes leads to blood and 
809 digestive disorders. In humans [145], burning sensations in the mouth and stomach,

810 headaches, a decrease in red blood cell count, bleeding, necrosis of the throat and stomach 811 and, in some cases, death, were observed in a humanitarian catastrophe in the USSR between 8121942 and 1947 caused by the ingestion of wheat that had suffered foot rot all winter [38,39].

813 The production of trichothecenes is favoured by cold and humidity [146] and studies on 814 various organisms have demonstrated the toxicity of these substances. In animals, vomiting is 815 observed after the ingestion and absorption of at least $10 \mathrm{mg}$ deoxynivalenol per $\mathrm{kg}$, together 816 with irritation of the mucous membrane lining the mouth and the oesophagus, with animals 817 refusing to eat after ingesting $2 \mathrm{mg}$ deoxynivalenol per $\mathrm{kg}$.

818

819 In plants, deoxynivalenol retards the germination and growth of wheat, and inhibits the 820 growth of the grain and the coleoptile tissues [147]. The phytotoxicity of mycotoxins is 821 generally estimated by means of coleoptile elongation tests [43,145]. In adult plants, 822 deoxynivalenol seems to circulate in the phloem, with the concentration of this molecule in 823 the plant following a descending gradient from the rachis, through lemmas and grains to the 824 peduncle [148]. In addition, from the fourth day after inoculation, the flower parts, rachis and 825 peduncle contain larger amounts of deoxynivalenol below the point of infection than above it 826 [149].

828 Fusarium can also produce mycotoxins of two other families: fumonisins, which are 829 recognised carcinogens [13,150] and zearalenone. Zearalenone belongs to the oestrogen 830 family. It perturbs reproductive hormone equilibrium and alters secondary sexual characters 831 [145]. Pigs are particularly sensitive to this toxin [145]. In the laboratory, it has been shown 832 that this compound also controls reproduction in the fungus that produces it, by regulating 833 perithecium production [151-153]. No phytotoxic effect of zearalenone has been observed in 834 coleoptile elongation tests [145].

836 To account for the small number of studies dealing with the mycotoxins produced by 837 Fusarium on wheat, it should be borne in mind that most of these studies have been carried 838 out in Europe and North America, where type A trichothecenes are rarely detected [154]. 839 Furthermore, fumonisins and zearalenone are found essentially on maize $[8,155]$. In addition, 840 zearalenone is considered to be only mildly toxic to humans [155]. 


\section{3-2. Effect of soil tillage}

843 Soil tillage seems to have similar effects on the production of mycotoxins and on the disease 844 itself (see part 2-1). Unlike chisel ploughing and direct drilling systems, mouldboard 845 ploughing decreases the concentration of deoxynivalenol in the grains $[19,101,156]$. In one 846 study, a significant positive correlation between deoxynivalenol concentration and the 847 intensity of soil tillage (ploughing or direct drilling) after a maize crop was observed [100].

848 Similarly, another study comparing three cropping systems involving ploughing (productive, 849 integrated and organic) with a direct drilling system over two years reported that levels of 850 deoxynivalenol, zearalenone and nivalenol contamination were highest for the direct drilling 851 system [55].

\section{3-3. Effect of the preceding crop}

854 The effect of the preceding crop is also similar for disease symptoms and deoxynivalenol 855 concentration. Deoxynivalenol concentration in wheat is $25 \%$ lower after a soybean crop than 856 after a wheat crop and 49\% lower after soybean than after maize [19]. Wheat following maize 857 in the rotation has been found to have deoxynivalenol concentrations six times higher than 858 those in wheat following another cereal (wheat, barley) or soybean [100]. In direct drilling systems, wheat crops following an oilseed rape crop contain $90 \%$ less deoxynivalenol than wheat crops following a maize crop [101]. As for soil tillage, only few studies have produced useful results.

862

863

864

865

866

867

868

869

870

871

872

873

874

875

\section{3-4. Effect of mineral nutrition}

We saw in section 2-3 that the effects of mineral nutrition on the disease are unclear. In contrast, there are fewer strong contradictions concerning the effect of mineral nutrition on mycotoxin production. This is probably because very few studies have focused on this question. Increases in nitrogen input from 0 to $80 \mathrm{~kg} / \mathrm{ha}$, result in increases in grain deoxynivalenol content; at levels above $80 \mathrm{~kg} / \mathrm{ha}$, a small but significant decrease was observed [119]. Urea-based fertilisation resulted in lower levels of deoxynivalenol in wheat grains than did ammonium nitrate in 1997, but this result was not observed the preceding year, in which no effect had been demonstrated [156]. Applications of ammonium-nitrateurea solution and nitramoncal did not give significantly different results [119]. Potassium, phosphorus and $\mathrm{pH}$ did not appear to affect deoxynivalenol concentration significantly [100]. A laboratory study showed that $\mathrm{Mg}^{2+}$ ions inhibit the elements responsible for inducing trichothecene synthesis [38]. 
877 These studies were empirical, and were not based on any particular assumption concerning

878 the mechanisms involved. It therefore remains difficult to extrapolate the results obtained.

879

\section{3-5. Effect of variety earliness}

881 Very few studies have focused on the effect of wheat variety earliness on the production of 882 mycotoxins. The earliest varieties seem to accumulate more deoxynivalenol than do late883 flowering varieties [157], possibly due to varietal differences but more probably due to 884 greater coincidence of the phase of maximum susceptibility in plants with the period most 885 favourable for spore dispersion. This trend appears to be based on the relationship between 886 the severity of the attack and the intensity of toxin contamination. The choice of variety is 887 therefore of key importance for combating the accumulation of toxins in the grains [158].

\section{3-6. Effect of fungicide treatments}

890 The application of a triazole fungicide, such as tebuconazole, decreases levels of 891 deoxynivalenol contamination in artificially inoculated crops with respect to those observed 892 in untreated controls [21,27,28,143]. However, conflicting results have been obtained [22]. 893 More generally, in conditions of natural contamination, the application of fungicides does not 894 significantly decrease the concentrations of deoxynivalenol and nivalenol and there is not 895 necessarily a correlation between the application of fungicides and the quantity of 896 deoxynivalenol and/or nivalenol found in the grains [6,55]. This may be accounted for by the 897 multitude of species present in fields and the relative specificity of fungicide treatments for 898 only one or a few species. Another hypothesis has also been put forward: too low a dose of fungicide may stimulate the production of deoxynivalenol by Fusarium in wheat grains [53].

This analysis shows not only that few studies have investigated the effects of cropping systems, but also that the characterisation of the disease in these studies is often severly

903 flawed. This makes it difficult to extrapolate and to interpret the results. To understand the 904 relationship between cropping systems and mycotoxin production, we therefore need to break down this relationship into two parts: the effects of cropping systems on the disease (symptoms, nature of the pathogenic agent) (section 2) and the relationship between the

907 disease and the production of mycotoxins, which may itself vary as a function of cropping 908 system. 
911 4- Relationship between the disease and toxin production

\section{4-1. Toxin production by the fungi}

914 Toxin production in fungi is controlled by many factors. One of the most important factors 915 intrinsic to the fungus is the genetic capacity of the pathogenic strain to produce toxins, in 916 terms of the quantity and type of toxins produced [34,159,160,161]. Thus, strains of $F$. 917 graminearum may, like F. culmorum, produce isomers of monoacetyldeoxynivalenol or 918 alternatively, like $F$. crookwellense, may produce acetyl derivatives of nivalenol [4]. Strains 919 of $F$. sambucinum may produce the T2 toxin whereas those of $F$. sporotrichioides produce 920 diacetoxyscirpenol (DAS) [4]. It should be noted that strains of $F$. graminearum $[60,159,162]$ 921 and of $F$. culmorum $[163,164]$ tend to produce either deoxynivalenol or nivalenol, but not both. Thus, the two toxins are generally not produced by the same strains, although the two types of strain often coexist in the same field [165]. Moreover, regionalisation of the types of strain at world level is observed for $F$. graminearum strains producing 3-acetyldeoxynivalenol and those producing 15-acetyldeoxynivalenol, with strains producing 3-acetyldeoxynivalenol predominating in Europe, China, Australia and New Zealand whereas those producing 15acetyldeoxynivalenol predominate in the United States [159]. Data for a collection of 188 strains of $F$. graminearum indicated that European and American strains produce essentially deoxynivalenol and are more aggressive than Nepalese strains, which produce either deoxynivalenol or nivalenol [166]. A negative correlation has been found between the production of zearalenone and that of trichothecenes (deoxynivalenol or nivalenol) by the spores of F. graminearum [52]. This appears to indicate that the production of these toxins

933 shares a common control process, which may play an important role in the ecology of $F$.

934 graminearum and $F$. pseudograminearum [52].

935

936 Other factors may also cause variations in toxin formation. These factors include the 937 substrate, the period of colonisation of the substrate by the strain, competition between 938 microorganisms [2,34,52,53], interaction between the pathogenicity of the strains and the 939 wheat variety [167,168] overall climatic conditions [51] and, more particularly, temperature 940 [2,52-54], humidity [2,52,53] and rainfall [54]. 
942 Other poorly understood factors extrinsic to the fungus also operate. For example, the protein

943 to carbohydrate ratio, which is important in mycotoxin synthesis [169], may play a role.

944 However, Bakan (1998)[38] showed that toxin formation is not necessarily controlled by food

945 stresses and is not necessarily linked to the growth of the fungus.

947 This last point is particularly important because many authors have suggested that the 948 trichothecenes (deoxynivalenol in particular) produced by Fusarium species play a role in the 949 aggressiveness or virulence of certain isolates [164,170-174]. Indeed, certain mutants 950 deficient in deoxynivalenol are less aggressive on wheat than the original strain [175]. 951 Similarly, the least virulent mutants of $F$. graminearum in terms of plant colonisation are 952 those unable to produce deoxynivalenol or nivalenol (mutations in the Tri5 gene, involved in 953 trichothecene production) [171]. Thus, trichothecenes are considered to be virulence factors in $954 F$. graminearum, during the infection of wheat $[145,175]$, and in $F$. culmorum, during the 955 infection of barley [164].

956

957 In conditions of artificial contamination with a given pathogenic strain or in natural 958 contamination conditions, several authors [19,27,90,100,147,164,176,177] have observed a significant, positive correlation between the incidence and/or severity of the disease and deoxynivalenol concentration (also reported by Bai et al., 2001[49] for 116 wheat lines). 961 Others [26,49,178,179] have demonstrated a significant correlation between deoxynivalenol 962 concentration and the fungal biomass of the grains (measured by assessing the amount of 963 ergosterol). These results suggest that new cultivars could be selected on the basis of 964 symptoms to ensure low levels of deoxynivalenol. However, exceptions were found among these lines: certain cultivars present severe symptoms with low deoxynivalenol levels, particularly those with moderate resistance to propagation of the pathogenic agent [49]. Thus,

967 the production of deoxynivalenol is not essential for the infection of grains [164]. 968 Furthermore, after the inoculation of five wheat varieties with a strain of $F$. graminearum, no 969 correlation was observed between deoxynivalenol concentration and the severity of infection 970 [172]. Similarly, after inoculation with a complex of species, no correlation was observed 971 between deoxynivalenol concentration and infection on wheat, barley or oats [178]. In 972 conditions of natural contamination, no correlation has been found between the intensity of 973 the disease on wheat and the concentration of deoxynivalenol [53,55,78], or between the 974 presence of Fusarium and the concentration of deoxynivalenol [154]. This lack of relationship 975 is also observed with other toxins, such as nivalenol [55]. A similar result was obtained with 
maize: after inoculation of the ear with $F$. poae, no relationship was found between the severity of the disease and toxin (nivalenol and fusarenon $\mathrm{X}$ ) production [180]. These differences in results may be due to the ranges of variation tested and the comparisons made not being the same. Some comparisons were made in the field and others in the laboratory; some were made after artificial inoculation with one or several species and others were made in natural contamination conditions.

The date of the attack and the species involved also affects the relationship between symptoms and toxin levels. Indeed, it is only to be expected that as the number of affected grains increases, so does the risk of major contamination by mycotoxins. However, a late attack may prevent the disease from reaching a high level of severity, even if very high levels of mycotoxins are produced. Thus, fungi and mycotoxins are detected before any visual symptoms of disease [148,181]. In addition, not all the species of the parasite complex responsible for head blight produce mycotoxins: Microdochium, for example, does not produce mycotoxins. Similarly, even among Fusarium species potentially capable of producing toxins, strains unable to produce toxins have been identified $[2,38,162,182]$. Other strains have been identified that produce far more toxin than the mean amount for all strains [183]. In addition to climate (particularly rainfall levels and temperature before and at flowering), the species profile of the fungi responsible for head blight also depends on agronomic factors such as soil tillage, nitrogen fertilisation, fungicide use, crop rotation and host genotypes [10]. Furthermore, the species of Fusarium potentially able to produce toxins cannot necessarily produce trichothecenes (the most studied mycotoxins) [183]. These observations indicate that it is possible for the plant to present symptoms in the absence of toxin production. However, the conditions of toxin productions in the field remain mostly unknown.

The relationship between the intensity or severity of symptoms and toxin production also depends heavily on the type of resistance carried by the plant. The severity of symptoms is known to depend heavily on plant resistance: certain genotypes limit the development of the mycelium in the grain, protecting the grain against degradation and limiting the visual signs of attack, but are not very tolerant of mycotoxins, with very high mycotoxin levels being recorded [49]. Conversely, other types of cultivar may present severe symptoms with only low mycotoxin levels [49]. 

Non-specific resistance

1012 It is not easy to identify cultivar resistances because the species of Fusarium responsible for 1013 head blight are saprophytes with a broad host-range and low levels of intraspecific variation, 1014 which is not the case for pathogens in general [6,18]. It should also be noted that all cultivars 1015 are susceptible to some extent, with even the least susceptible cultivars displaying only 1016 moderate resistance $[16,49,50]$. Resistance to the development of the fungus and to the 1017 accumulation of trichothecenes is probably controlled by different genes [43].

\section{Heritability of the resistance}

1020 The low specificity of Fusarium and Microdochium generates polygenic resistance in the 1021 plant, involving genes with various degrees of dominance [43,184]. It is the combination of 1022 these genes, controlled by the environment [176] that results in genetic resistance in the plant 1023 [13].

The inheritance of resistance can be described by a dominance-additive effect model, in which the additive effect is the essential factor (results based on diallel analyses) $[9,25,185]$. Several studies [18,25,186-188] have demonstrated the existence of resistance genes on 18 of the 21 chromosomes (1B, 2A, 3, 3B, 4B, 5A, 6B, 6D, 7A, 7B etc.). Three pools of genes are responsible for three different genetic constitutions conferring different types of resistance to head blight in wheat: in Eastern European winter wheats, in Japanese and Chinese spring wheats and in Brazilian and Italian spring wheats [189]. The most commonly used source of resistance is undoubtedly Sumai 3 (in China), in which stable resistance is combined with valuable agronomic characteristics (yield potential and resistance to rusts and powdery mildew) $[18,43,190]$. The resistance of this genotype, like that of Frontana (a Brazilian variety) and Nobeokabouzu-komugi (a Japanese variety) - the two other major sources of resistance - is based on two or three genes with additive effects, the sensitivity of which varies with a multitude of minor genes $[9,18,191]$. The crossing of Frontana and Sumai 3 resulted in the detection of two major quantitative trait loci (QTLs) [13]. These sources of resistance are of great potential value for future crosses and the selection of new cultivars because they are stable.

1042 Resistance to head blight in wheat is horizontal (non-specific) and thus protects against all species of Fusarium and Microdochium [6,18,43,192]. 
1045 No correlation has been found between seedling resistance and resistance in the ear. Thus, a given cultivar may be susceptible at the seedling stage and resistant at the adult stage or vice versa. Alternatively, it may be susceptible throughout the crop cycle [5]. The activation of resistance genes during an attack depends on the developmental stage of the wheat, varying throughout the crop cycle $[5,47,49,50,90]$. Peak toxin accumulation also depends on the cultivar grown [193]. Finally, it should be noted that the duration of the induction period and the intensity of the response to the defence mechanisms induced also determine the defence of the plant [43]. Tetraploid wheats are more resistance to head blight than are diploid wheats [194].

1054

The defence or resistance mechanisms of the plant depend not only on growth stage, but also on the humidity and temperature of the air [47] and on the genetic capacity of the wheat cultivar $[5,18,49,50,90]$. However, no plant host defence reaction has ever been detected macroscopically or histologically on the outside of the glumes [12]. In addition, no cellular or anatomical characteristics [13,50] or histological features [50] have been found to be associated with resistance or susceptibility. However, the techniques currently used, and ultrastructural studies in particular, have shown that susceptible and resistant wheat varieties react differently to infection and to the propagation of pathogens [94].

This implies the existence of multiple mechanisms of defence or resistance in plants, both active (including physiological processes) and passive (including morphological characteristics such as avoidance), and/or tolerance [5]. Five types of cultivar resistance are

\section{Types of resistance}

1070 Type I: Resistance to initial infection [50]. Many cultivars may be resistant to initial 1071 infection. According to Nakagawa (1955) [195], this type of resistance is controlled by 1072 dominant genes at three loci subject to epistasis. This type of resistance may be passive or 1073 active.

1075 Passive mechanisms involve morphological characteristics facilitating avoidance, making it 1076 possible for the plant to decrease the severity of the disease. The receptiveness of cultivars to 1077 the disease is lower in cultivars with awns [5,14,134], regardless of varietal differences in 
1078 resistance [134]. Similar results have been obtained with wheat, barley [134] and oats 1079 [45,134]. Similarly, the height of the ear and its angle with respect to the stem are negatively 1080 correlated with the severity of head blight and the accumulation of deoxynivalenol [191]. The 1081 receptiveness of cultivars to Fusarium and/or Microdochium is also lower for ears with a 1082 large peduncle — at least $15 \mathrm{~cm}$ between the flag leaf and the ear [5] — and/or without 1083 growth arrest, reducing the area in contact with the conidia and the duration of grain humidity 1084 [5].

A cultivar well adapted to its environment is also a criterion for resistance to head blight $[18,43]$. Indeed, a canopy with too many ears $[5,16]$ or a flowering season that lasts too long $[2,90]$ is likely to result in slightly higher susceptibility to the disease. The resistance of a variety may be evaluated as a function of the duration of time for which the flowers remain open and of the percentage of flowers presenting autogamous flowering (unopened anthers) and allogamous flowering (opened anthers) [50]. Studies have shown either that resistance to head blight may be maximised by the use of early varieties [133] or that earliness has no importance [135]. However, the importance of this factor seems to depend on the date of the attack and, thus, on the year and region studied. Similarly, only one study has investigated the effect of flowering date on mycotoxin contamination: the time of infection by $F$. culmorum that produces the greatest amount of deoxynivalenol contamination is restricted to a short period during anthesis [87]. However, like disease, flowering period and variety growth duration probably depend essentially on the year and region concerned: the only valid way to determine the characteristics (period and duration of flowering and growth duration) of varieties adapted to a given region is to carry out frequency analysis of the climate, which requires the monitoring of mycotoxin contamination in a given region over many years.

1103 It is widely accepted that morphological characteristics are less important than the possible physiological resistance of cultivars [9]. This physiological resistance includes all the other possible mechanisms. Active mechanisms include defence reactions concerning the physiological qualities of the cell that limit colonisation of the plant by the fungus, such as the activation of enzymes degrading the fungal cell wall. Such a mechanism has been proposed for pathogenesis-related proteins (PR proteins) and hordothionins [196]. Mechanisms of this type may account for the induction of several defence genes 48 hours after inoculation, including genes encoding chitinases, glucanases, peroxidases and thaumatin-like proteins (TLP) $[197,198]$. 
1113 The endo- and exochitinases in plant cell walls help to improve plant resistance by 1114 hydrolysing chitin, a protective polysaccharide present in the cell walls of the pathogens 1115 [18,199]. The various types of chitinase known do not have the same effects [200]: the class I 1116 chitinase-a of rice strongly inhibits re-extension of the hyphae and is present in mature cells in 1117 particular. It collects at the tip of the hyphae, on the lateral walls and in the septa and has a 1118 very high affinity for fungal cell walls. This enzyme releases a large amount of reducing sugar 1119 from the fungal cell walls. It also ligates the lateral walls and the septa, is part of the walls of 1120 mature cells and degrades mature chitin fibres. In contrast, the class II chitinase-c of rice is 1121 found essentially at the tip of the hyphae, which it ligates before degrading young chitin 1122 fibres. Thus, chitinase-a is more effective than chitinase-c at inhibiting the growth of the 1123 fungus [200].

1125 The antimicrobial activity of thionins is attributed to their capacity to create pores in the 1126 membranes of fungi by means of interactions between the phospholipids and 1127 phosphoinositides of the membrane or by decreasing the activity of enzymes by reducing 1128 disulphide bonds [199].

1130 Thaumatin-like proteins may have two modes of action: they may be specifically produced in 1131 response to the presence of pathogenic fungi in a certain number of plants, including wheat 1132 [201] or they may disturb the signal transduction cascade in the cell, increasing tolerance to 1133 trichothecenes and favouring the development of fungi in the plant [198]. A trypsin-like 1134 protease produced by F. culmorum may be one of the key enzymes in the colonisation of 1135 plants by the fungus [202]. Indeed, the presence of this enzyme in barley has been shown to 1136 be correlated with the degradation of specific buffer proteins in infected grains [203]. The 1137 alkaline protease produced by $F$. culmorum is also involved in the colonisation of barley and 1138 wheat grains [204]. Peroxidases (POX) are oxidoreductive enzymes involved in the 1139 construction of the cell walls of plant hosts (phenol oxidation, suberisation, lignification) 1140 during defence reactions against pathogenic agents [205]. The concentration of POX increases 1141 significantly during the milk stage in wheat anthers inoculated with $F$. graminearum, whereas 1142 this is not the case in healthy wheat [205].

1144 Polyphenol oxidases (PPO) are involved in the oxidation of quinone polyphenols (a microbial 1145 component) and in the lignification of plant cells during microbial invasion [205]. The 
1146 specific activity of PPO is maximal during the milk stage in wheat and declines rapidly 1147 thereafter [205]. Levels of PPO activity are higher in resistant than in susceptible varieties and 1148 increase following inoculation with $F$. graminearum [205].

1150 One possible strategies for reducing the risk of mycotoxin contaminations is the development 1151 of more resistant transgenic crops. Three approaches are possible [206]: (i) transgene1152 mediated control of the ability of Fusarium to infect and colonise the ear, through the 1153 overproduction of specific antifungal proteins and metabolites, or by increasing the plant's own defense systems in kernel tissues; (ii) the prevention of mycotoxin biosynthesis, or the detoxification of mycotoxins in plants and (iii) the development of more resistant plants based on transgenic crops engineered to produce a Bacillus thuringiensis $(\mathrm{Bt})$ toxin. Some Bt maize hybrids have the potential to reduce the level of fumonisin B produced by $F$. verticillioides [206]. This effect probably results from a decrease in sensitivity to one of the possible means of ear tissue contamination: attack by insects [206,207]. Indeed, Bacillus thuringiensis (BT) is known to produce proteins toxic to insects [208]. This strategy has not yet been applied to wheat.

1163 Type I resistance is generally estimated by determining the percentage of spikelets infected 1164 seven to 21 days after inoculation or at maturity [9]. However, the number of infected 1165 spikelets does not necessarily reflect the total damage caused by the pathogen. The symptoms also depend on the severity and rapidity of rachis invasion by the pathogen.

Type II: resistance to (kinetic) propagation of the pathogenic agent in the tissues [50].

1169 The mechanisms involved in this type of resistance are purely active, such as inhibition of the 1170 translocation of deoxynivalenol [18] by an ABC (ATP-binding cassette) transporter protein, 1171 the Pdr5p (pleiotropic drug resistance) [209] or increasing the stability of cell membranes

1172 [18]. This process limits the propagation of Fusarium culmorum and F. graminearum [95] 1173 from the glumes [18,26] and/or ovaries and glumes to the rachis and the pedicel [94-96]. The 1174 endo- or exocellular migration [94-96] of the fungus leads to a series of changes in host cells, 1175 including degeneration of the cytoplasm, organelles (e.g. chloroplasts) and cell wall [95,96] 1176 by enzymes such as cellulases, xylanases and pectinases [95,96] produced during the 1177 penetration and colonisation of the tissues of the wheat ear [95,96]. Once attacked, susceptible 1178 varieties respond to infection only by forming a very thin wall in the periplasmic space of the 1179 infected tissues [94]. In contrast, resistant varieties react strongly: extensive formation of a 
1180 very thick wall located close to the infected cells and of a large papilla formed by the rapid and intense deposition of callose ( $\beta$-1,3-glucan), lignin and other compounds [94]. Three days after inoculation, defence structures are more solid, with denser cell walls, particularly in cells adjoining contaminated cells, in the envelopes of cultivar Frontana (resistant) than in those of cultivar Agent (susceptible) [210]. The process of lignification may be involved in plant defences, establishing mechanical barriers to pathogen invasion [94,210], modifying the structure of cell walls and making them more resistant to the degradative enzymes produced by the pathogen [210]. Furthermore, lignification may inhibit or reduce the diffusion of small molecules or ions, including the mycotoxins secreted by the fungal hyphae in the host cells [94,210], and reduce the movement of nutrients from the host cell to the pathogen [210]. In addition to the lower permeability of the cell membranes in resistant genotypes, the basis of the inhibition of deoxynivalenol translocation may also involve a lower affinity of the membrane for deoxynivalenol [26]. This hypothesis is based largely on observations in two types of mutant yeast [144]. One of these types of mutant yeast presents a low affinity and low cell membrane permeability for trichothecenes, and in the other, the 60S ribosomal subunit has a lower than normal affinity for these toxins. The target of deoxynivalenol is a cytoplasmic peptidyl transferase [211]. Mammalian and fungal cells have a modified peptidyl transferase that is tolerant to trichothecenes [211]. In cases of type II resistance, the trichothecenes seem to bind to the ribosomal 60S subunit, by methylation, thereby blocking the translation of the RNA and inhibiting protein synthesis $[38,43,145]$. This inhibition leads to the inhibition of peptidyl transferase activity, opposing resistance to trichothecenes. In cases in which the membrane is not permeable to deoxynivalenol, a virulence factor promoting fungal growth [26] the propagation of the pathogen agent is restricted. Thus, three to five days after inoculation, susceptible varieties display more extensive propagation of the fungus, higher levels of deoxynivalenol accumulation and fewer pathological changes in infected tissues [94]. A hypersensitive reaction is also possible [18].

This type of resistance can be identified visually by observing the symptoms, which reflect the propagation of the disease from the point of infection [9]. It is also characterised by low levels of ergosterol (an indicator of fungal biomass) [3]. The most well known variety displaying this type of resistance is Sumai 3 [189].

1212 Type I and II resistances may be combined in a given genotype [18,50]. This results in a 1213 variety tolerating the invasion of grains that displays no symptoms on the grains [50]. 
1214 Similarly, the number of infected spikelets does not necessarily reflect the total amount of 1215 damage done by the pathogen. The amount of damage also depends on the severity and 1216 rapidity of the invasion of the rachis by the fungus. Thus, the three principal sources of 1217 variation in the expression of symptoms are the environment [57], the species and/or strain of 1218 Fusarium [57,212] and factors involved in the maturation of cereals that also play an 1219 important role in the epidemiological profile of the disease [212]. Wheat contamination is 1220 favoured by high levels of precipitation in the ten days preceding grain maturity, but only if 1221 the minimum temperature in the ten days following ear emergence is sufficiently high [212].

1222 It should be noted that these factors are varietal and also depend on the fungal species concerned [212].

It seems likely that, in certain cases, the production of trichothecenes (deoxynivalenol in particular) by fungi activates their development (hyphal growth: type II resistance) and colonisation (type I resistance), by interfering with the defence response of the plants $[18,26,175,213]$. The quantity of trichothecenes in the grains is controlled by the degradation of deoxynivalenol and by the tolerance of the plants to this toxin [18].

1231 Two other types of resistance have recently been discovered. Both involve defence reactions 1232 directed against trichothecenes, in which the synthesis of this toxin is blocked or its 1233 degradation enhanced [147,214].

Type III: resistance involving the capacity to degrade deoxynivalenol [214-216]. In some varieties (e.g. Fredrick), enzymatic systems for the detoxification (degradation) of trichothecenes, involving the acetyltransferase Ayt1p [209] for example, have been identified based on a decrease in the amount of deoxynivalenol six weeks after inoculation [215]. Deoxynivalenol begins to accumulate three days after inoculation (four days according to Savard, 2000[149]) of an ear. The concentration of this toxin increases, peaking after six weeks, and then decreases naturally to a concentration that remains constant thereafter at maturity, harvest and during grain storage [90].

1244 This resistance was identified by inoculating grains of wheat, rice and triticale with a single strain of F. graminearum [214]. This study showed that the varieties most resistant to pathogen development (low F. graminearum biomass, as estimated from ergosterol content) have a higher ergosterol/deoxynivalenol ratio than do varieties more susceptible to the 
development of this pathogen. This implies that the susceptible varieties are able to degrade the deoxynivalenol produced by the large number of fungi present.

This type III resistance, characterised by a high ergosterol/deoxynivalenol ratio [213], protects against symptoms due to the propagation of the fungus. However, there may nonetheless be a decrease in the number or weight of grains and their size [9]. This resistance is estimated visually by measuring yield and by comparing the values obtained for ears with and without symptoms [9] but this estimation also depends on resistance to grain infection.

Type IV: resistance involving tolerance to high concentrations of dexoynivalenol (apparent insensitivity to trichothecenes) [3].

1259 Like cultivars with type II resistance linked to the modification of peptidyl transferase, the target of deoxynivalenol, cultivars with type IV resistance also have a modified peptidyl transferase [3]. This enzyme stabilises the membrane, conferring greater tolerance to trichothecenes [43]. It has also been suggested that changes in the permeability of the cell wall or in the signal transduction cascade in the cell inducing greater tolerance to trichothecenes by thaumatin-like proteins can account for this type of resistance [198].

For a given severity of disease, this resistance is generally estimated by a higher level of deoxynivalenol compared to other genotypes [9].

\section{Type V: resistance to grain infection [5].}

This type of resistance results in differences in yield despite similar levels of attack or, conversely, little effect on yield despite the evident presence of the disease after artificial inoculation [5,9,217]. In contrast to the other types of resistance, this type of resistance may not correspond to a physiological process, but rather to the "morphological" expression of an interaction between various complex processes: resistance of types II, III and IV.

\section{4-3. Resistance to head blight according to the composition of plant tissues} In addition to genetic resistance, the composition of plant tissues is also a criterion of resistance to the development and/or propagation of the fungus and its toxins. The susceptibility of wheat cultivars is linked to the concentration of choline in the ear at anthesis

1280 [218], superoxide dismutase activity in the ears in cases of contamination by deoxynivalenol 1281 or F. graminearum [219] and the concentration of p-coumaric acid, one of the phenolic acid 
1282 precursors of lignin [210]. The quantity of this compound in the ear is much higher after 1283 inoculation of the glumes, envelopes and rachis with $F$. culmorum than in uninoculated 1284 tissues [210]: this is thus a very important factor determining the susceptibility of crops. The 1285 accumulation of an acetyltransferase encoded by FsTri101 in the endosperm and glumes of 1286 wheat confers partial protection against $F$. graminearum [220]. Similarly, feluric acid in the 1287 ears seems to be involved in resistance to ear blight in maize [221], although healthy and 1288 inoculated ears contain similar amounts of this compound [210].

The composition of wheat and barley grains may also affect contamination levels [134]. Couture [134] suggested that a high gluten content in hard wheats and a high starch/protein ratio in malting barley could protect the crop against head blight.

The relative sugar content of leaves or stems has been proposed as an indicator of susceptibility to diseases [222]. Unlike powdery mildew, head blight is favoured by a low sugar content of the tissues [222]. Similar results were obtained in studies of stem blight in maize, involving a parasitic complex consisting of $70 \%$ Fusarium graminearum [129]. The refraction index of the sap of a section of pressed stem is used to assess the sugar content of stem bases (Bertrand's method) and it has been shown that the higher the sugar content of maize stems, the more resistant to stem blight the maize is likely to be [129]. Messiaen [129] also indicated that $F$. graminearum is equally able to use sugars, starch and cellulose as sources of carbon, and proteins, ammonium salts or nitrates as sources of nitrogen. Thus, Fusarium makes us of storage proteins, and degrades the cell walls and starch grains of infected grains $[41,42]$.

\section{Conclusion}

1307 Head blight is a widespread disease with major consequences for health. However, it has been

1308 little studied in the open field. Indeed, field studies of the epidemiological cycle of the disease 1309 are hindered by a major problem: identification of the species and strains making up the 1310 parasitic complex of the inoculum. A mean of five to seven species, and up to nine in total 1311 [8], may be present in the same field in the same year. These species can only be identified 1312 after culture in Petri dishes and the observation of a collection of morphological criteria 1313 (colour, macroconidia, microconidia, ascospores, chlamydospores of a strain), which requires 
1314 the conservation of living spores, or molecular genotyping (which remains difficult for these 1315 species).

1317 In the laboratory, the various steps in the plant infection process and in mycotoxin production 1318 are essentially studied from an environmental viewpoint. Uncertainties remain concerning, in 1319 particular, the necessity of inducing the development of perithecia by exposure to ultraviolet 1320 light, the natural climatic conditions in which spores are released (macroconidia and ascospores) and the sensitivity of these mechanisms to environmental factors.

In the field, spore dispersal depends on climatic factors in two ways: climatic factors affect spore production (see section 1-2) and strongly regulate spore release. However, the climatic conditions required for spore release are unclear. This is probably due to the difficulties involved in identifying and isolating the various types of spore (ascospores or macroconidia). Furthermore, the results obtained probably depend on the maturity of the spores: four periods of release over a period of 20 to 30 days have been observed.

However, it seems that macroconidia are dispersed by means of splashing during rainfall. In contrast, the release of ascospores is only triggered by rainfall (or high humidity), resulting in the rehydration of the perithecia after a dry period. The true release of the ascospores occurs several days later, depending on air humidity. Ascospore release, in F. graminearum in particular, appears to be periodic.

Although the dispersal pathways of the spores are known (splashing for the macroconidia and/or ascospores and wind dispersal for ascospores only) and long-distance dispersal appears to be possible, the maximum dispersal distance and the contaminating potential of splashing and wind dispersal have yet to be determined. Furthermore, local contamination seems to predominate in the epidemiological profile of the disease in that two neighbouring plots planted with the same variety may present very different levels of contamination.

The importance of local contamination raises the question of the hypothetical contamination

1344 of spikelets via the systemic route. This question remains unanswered because as far as we 1345 know no study has shown, microscopically, the systemic colonisation of the spikelets and the 1346 growth of the fungus in plant tissues (or the impossibility of such colonisation). Similarly, the 1347 existence, conditions of existence and potential importance of such contamination have not 
been precisely determined. Conflicting results have been obtained and it is possible that this route of contamination is possible only for a few plant genotypes, for a few fungal species or strains, or for a few plant-fungus interactions. Indeed, interactions between plants and pathogens have been observed during infection. We can therefore presume that the virulence characteristics of the infecting fungal strain, the resistance of the plant and the virulenceavirulence interaction between plants and pathogens determines the capacity of the plant to be infected by mycelium and/or spores, the speed of infection (colonisation) of the ear by the fungal mycelium and the amount of mycotoxins present in the grains at harvest. These phenomena, like the production of inoculum, also depend on climate.

The choice of variety is a practical consideration that may affect plant infection: the date and site of fungal penetration, the propagation rate and the intensity of the consequences of the attack (severity of symptoms and/or amount of toxins). Indeed, the choice of variety determines the major mechanisms of varietal resistance activated. However, it should be stressed that although various types of resistance have been identified, they have not yet been entirely elucidated. Furthermore, the types of varietal resistance have not yet been characterised for most wheat varieties, which makes it difficult to compare varieties in a particular area. Together with genetic characteristics, sowing date and climate determine the date at which the crop is most susceptible to infection.

The extent of infection depends directly on the quality of inoculum, the primary source of which is crop residues. In the epidemiological cycle of the disease, residues probably modify the conservation and development of the fungus and spore dispersal, with effects depending on the amount of residue present (which depends on soil tillage methods and the preceding crop) and their nutritive value for the pathogen and for the plant (which also depends essentially on the preceding crop). The high levels of nitrogen in maize residues may result in a longer period of residue colonisation by Fusarium, strengthening pathogen populations, and stimulating their development. If too many crop residues are present, spore dispersal by splashing may be physically limited by obstacles. Conversely, if the fungus has access to too few residues or residues insufficiently rich for it to complete its life cycle and to develop, then the fungus is likely to produce fewer spores and to disperse less effectively. There is also an interaction between these factors. Limited soil tillage methods increase the density of residues on the surface of the soil and hence increase the quantity of inoculum available, particularly if

1381 the preceding crop is a potential host of the fungus (e.g. maize or durum wheat). Mycelium 
1382 development and the production and dispersal of spores therefore depend on climate and 1383 irrigation.

1385 Although there is broad agreement among scientists and advisers concerning the effects of 1386 soil tillage, irrigation and preceding crop on both disease severity and contamination by 1387 mycotoxins, the cause of these effects remains unclear. In addition, uncertainties remain 1388 concerning the survival of the fungus and its capacity to sporulate in soil, according to soil 1389 aeration, porosity and light penetration, all of which are affected by soil tillage. Similarly, the role of the compounds generated by the degradation of crop residues and the rate of residue degradation - which depend on soil tillage, the nutritive value of the preceding crop and the microclimate of the residues, which itself depends on irrigation and its relationship to mineral composition (nitrogen, silicon, depending on the preceding crop) - make it difficult to predict the quantitative effects of soil tillage, preceding crop and irrigation.

Other unanswered questions remain concerning the effect of residue degradation on competition between microorganisms and/or plant resistance (notably by means of differences in mineral nutrition).

The effect of mineral nutrition on disease severity and mycotoxin contamination, if indeed there is one, remains unclear. The mineral balance of the soil influences pathogen populations and should therefore have repercussions for the development of Fusarium. The composition of plants, in terms of nitrogen and silicon, for example, probably affects the growth and development of the fungus, although this has not been explicitly demonstrated in wheat for several reasons: equilibrium between the various elements, fertilisation date, link with Fusarium foot rot etc. A canopy with unlimited mineral nutrition develops well. This development slightly modifies the environmental conditions of the residues, which may in turn modify the rate of residue degradation. If this is indeed the case, then the capacity of the fungus to sporulate and of the spores to disperse may be affected.

The role played by canopy density, in terms of crop plant and weed densities, and in the development of epidemics of the disease remains to be determined. Weeds may carry

1413 Fusarium, but is their role limited to that of an intermediate host (during splashing) or do they 1414 act as a source of inoculum? If they serve as a source of inoculum, how many spores are 1415 produced on weeds? Weeds probably also play an indirect role, modifying mineral nutrition 
1416 and/or microclimate by increasing plant population density. The overall density of plants in 1417 the canopy also depends on sowing density and the tillering capacity of the variety. Thus, 1418 weeds may affect the number of spores produced, spore maturation and/or spore dispersal.

1419 The uncertainties that remain probably arise at least in part from variations in the role played

1420 by weeds according to the type or family of weeds concerned and competition with the crop:

1421 date of emergence, density etc. (which also depends on climate). Although canopy density 1422 (crop plus weeds) seems likely to play a role, we cannot be sure of the nature or magnitude of 1423 this effect.

1425 It also seems clear that competition between microorganisms on the leaves and ears is likely 1426 to have an effect, but this is difficult to study in the field and necessarily depends on the 1427 fungicides used and on canopy development.

1429 Five types of varietal resistance have been identified to date. They affect the penetration of 1430 the fungus into the plant (type I), infection kinetics (type II), the expression of the infection 1431 (symptoms; type III), the consequences of infection (quantity of mycotoxins produced, yield; 1432 type IV) and grain infection (type V). This complexity of plant resistance complicates any 1433 study of several varieties. In such studies, caution is required when interpreting results 1434 analysing the relationships between cultural practices and symptoms, between symptoms and 1435 the quantities of mycotoxins produced and between cultural practices and the mycotoxins 1436 produced.

In conclusion, the relationship between disease symptoms and mycotoxin contamination is of key importance. The conditions in which this relationship is purely qualitative and those in which it also has a quantitative element are unclear. If we are to propose effective methods for

1441 the prevention of grain contamination by toxins, we must improve our understanding of this 1442 relationship, especially as concerns the role of the cropping system. Investigation of the 1443 effects of crop management and crop rotation on the profile of Fusarium species and strains 1444 obtained within a cereal field, and the conditions in which the potential for toxin production is expressed in agricultural environments, should be a research priority.

\section{Acknowledgements}


1448 We thank Alex Edelman \& Associates for their help in translating this paper from French into

1449 English. We also thank Alain Bone for tracking down the references and Stéphanie Pineau for 1450 help with the preparation of the manuscript.

\section{References}

1453 1. D. Atanasoff, Fusarium blight (scab) of wheat and other cereals, Journal of $1454 \quad$ Agricultural Research, 20(1), 1920, 1-32.

1455 2. J.C. Sutton, Epidemiology of wheat head blight and maize ear rot caused by Fusarium 1456 graminearum, Canadian Journal of Plant Pathology, 4, 1982, 195-209.

1457 3. Y.Z. Wang, J.D. Miller, Effects of Fusarium graminearum metabolites on wheat 1458 tissue in relation to Fusarium head blight resistance, Journal of Phytopathology, 122, 1988, 118-125.

1460 4. J.D. Miller, R. Greenhalgh, Y. Wang, M. Lu, Trichothecene chemotypes of three Fusarium species, Mycologia, 83, 1991, 121-130.

1462 5. A. Mesterhazy, Types and components of resistance to Fusarium head blight of wheat, 1463 Plant Breeding, 114, 1995, 377-386.

1464 6. D.W. Parry, P. Jenkinson, L. McLeod, Fusarium ear blight (scab) in small grain 1465 cereals - a review, Plant Pathology, 44, 1995, 207-238.

1466 7. M. McMullen, R. Jones, D. Gallenberg, Scab of wheat and barley: a re-emerging 1467 disease of devastating impact, Plant Disease, 81, 1997, 1340-1348.

1468 8. A. Bottalico, Fusarium diseases of cereals: species complex and related mycotoxin 1469 profiles, in Europe, Journal of Plant Pathology, 80(2), 1998, 85-103.

1470 9. J.C. Rudd, R.D. Horsley, A.L. McKendry, E.M. Elias, Host plant resistance genes for 1471 fusarium head blight : sources, mechanisms, and utility in conventional breeding systems, Crop Science, 41(3), 2001, 620-627.

10. A. Bottalico, G. Perrone, Toxigenic Fusarium species and mycotoxins associated with head blight in small-grain cereals in Europe, European Journal of Plant Pathology,

1476 11. F.T. Bennett, Fusarium species on British cereals, Annals of Applied Biology, 20(2), 1933, 272-290.

1478 12. G.W. Pugh, H. Johann, J.G. Dickson, Factors affecting infection of wheat heads by Gibberella saubinetii, Journal of Agricultural Research, 46, 1933, 771-797. 
1480 13. P. Ruckenbauer, H. Buerstmayr, M. Lemmens, Present strategies in resistance breeding against scab (Fusarium spp.), Euphytica, 119, 2001, 121-127.

14. R. Cassini, Facteurs favorables ou défavorables au développement des fusarioses et septorioses du blé. In "Proceeding of meeting of sections cereals and physiology" (Eucarpia, ed.), Dijon, 1970, pp. 271-279.

15. R.A. Daamen, C.J. Langerak, W. Stol, Surveys of cereal diseases and pests in The

16. D. Caron, Les Fusarioses. In "Maladies des blés et orges", (ITCF, ed.), 1993, pp. 3039.

17. P. Jenkinson, D.W. Parry, Splash dispersal of conidia of Fusarium culmorum and Fusarium avenaceum, Mycological Research, 98, 1994a, 506-510.

18. T. Ban, Studies on the genetics of resistance to Fusarium head blight caused by

19. R. Dill-Macky, R.K. Jones, The effect of previous crop residues and tillage on Fusarium head blight of wheat, Plant Disease, 84, 2000, 71-76.

20. R. Ioos, B. Bakan, Study of the Fusarium spp. from cereal grains and their related

21. C. Maumené, M. Leuillet, D. Caron, F. Henriot, Incidence des fongicides et de la mycotoxins. In "AFPP - $6^{\text {ème }}$ conférence internationale sur les maladies des plantes", variété sur le risque de contamination du blé tendre par le déoxynivalénol (DON) en france : premiers résultats. In "AFPP - $6^{\text {ème }}$ conférence internationale sur les maladies des plantes", Vol. 1, Tours, France, 2000, pp. 459-466.

22. D.R. Simpson, G.E. Weston, J.A. Turner, P. Jennings, P. Nicholson, Differential

23. R.J. Cook, A.A. Christen, Growth of cereal root-rot fungi as affected by temperaturewater potential interactions, Phytopathology, 66, 1976, 193-197. with spring wheat heads, Canadian Journal of Plant Pathology, 7, 1985, 79-82. 
1513

1514

1515

1516

1517

1518

1519

1520

1521

1522

1523

1524

1525

1526

1527

1528

1529

1530

1531

1532

1533

1534

1535

1536

1537

1538

1539

1540

1541

1542

1543

1544

1545

25. C.H.A. Snijders, Diallel analysis of resistance to head blight caused by Fusarium culmorum in winter wheat, Euphytica, 50, 1990c, 1-9.

26. C.H.A. Snijders, C.F. Krechting, Inhibition of deoxynivalenol translocation and fungal colonization in Fusarium head blight resistant wheat, Canadian Journal of Botany, 70, 1992, 1570-1576.

27. S. Homdork, H. Fehrmann, R. Beck, Effects of field application of tebuconazole on yield, yield components and the mycotoxin content of Fusarium-infected wheat grain, Journal of Phytopathology, 148, 2000, 1-6.

28. L.N. Jorgensen, Control of Fusarium ear blight in winter wheat [Danish] (abstract). In "17th Danish Plant Protection Conference II, Site-specific crop protection, decision support, pests and diseases, ear blight", Denmark, 2000.

29. W.G. Smith, "Diseases of field and garden crops. Cité par Parry, 1995," London, MacMillan and Co, 1884, pp. 208-213.

30. A. Mesterhazy, A.K. Rowaished, Analysis of symptoms caused by Fusarium graminearum Schwabe and its relation to powdery mildew infection in wheat, Acta Phytopathologica Academiae Scientiarum Hungaricae, 12(3-4), 1977, 289-301.

31. B. Carlier, Les fusarioses : des maladies dures à combattre, Jeunes agriculteurs, 557, 2001.

32. W. Ahrens, H. Fehrmann, Attack of wheat by Septoria nodorum and Fusarium ear scab. I- crop loss analysis, Journal of Plant Diseases and Protection, 91(1), 1984, 4258.

33. V. Le Boulc'h, S. Bedouret, V. Poyet, T. Barchietto, D. Hazouard, I. De Paepe, J.M. Seng, Un test innovant pour contôler la qualité sanitaire des céréales : détection des champignons potentiellement producteurs d'une famille de mycotoxines, les trichothécènes. In "AFPP - $6^{\text {ème }}$ conférence internationale sur les maladies des plantes", Vol. 1, Tours, France, 2000, pp. 451-458.

34. P. Galtier, C. Comera, I. Oswald, O. Puel, Mycotoxines : origines et toxicités. In "AFPP - $6^{\text {ème }}$ conférence internationale sur les maladies des plantes", Vol. 1, Tours, France, 2000, pp. 77-86.

35. J. Gilbert, A. Tekauz, Review: Recent developments in research on fusarium head blight of wheat in Canada, Canadian Journal of Plant Pathology, 22, 2000, 1-8.

36. J. Chelkowski, Fungal pathogens influencing cereal seed quality at harvest. Cité par Ruckenbauer et al. 2001. In "Cereal grain: mycotoxins, fungi and quality in drying and 
storage", (Chelkowski, ed.), Developments in Food Science, 26, Elsevier, Amsterdam, 1991, pp. 53-56.

37. D. Thouvenot, Moisissure et mycotoxine. In "Mycotoxines : un prochain enjeu de sécurité alimentaire ?" (CERAAF, ed.), 2002, pp. 14-17.

38. B. Bakan, Approche physiologique de la biosynthèse des trichothécènes par Fusarium, Thèse INA-PG, 1998, pp. 150.

39. D.R. Vidal, Propriétés immunosuppressives des mycotoxines du groupe des trichothécènes, Bulletin de l'institut Pasteur, 88, 1990, 159-192.

40. J.F. Quillien, "Les mycotoxines," Institut National de la Recherche Agronomique, France, 2002, pp. 24.

41. D.B. Bechtel, L.A. Kaleikau, R.L. Gaines, L.M. Seitz, The effects of Fusarium graminearum infection on wheat kernels, Cereal Chemistry, 62(3), 1985, 191-197.

42. L.M. Seitz, W.T. Yamazaki, R.L. Clements, H.E. Mohr, L. Andrews, Distribution of deoxynivalenol in soft wheat mill streams, Cereal Chemistry, 62(6), 1985, 467-469.

43. F. Eudes, Etude de l'impact des trichothécènes de Fusarium chez le blé et sélection in

44. IARC, Some naturally occurring substances: food items and constituents, heterocyclic

46. L.J. Francl, Development of Fusarium head blight in relation to environment and

47. A.L. Andersen, The development of Gibberella zeae head blight of wheat,

48. R. Cassini, "A propos des dégâts provoqués par Fusarium roseum dans les cultures de céréales du bassin parisien," Comptes Rendus de l' Académie d'Agriculture de France, and deoxynivalenol accumulation in wheat, Plant Breeding, 120, 2001, 1-6. 
50. H.W. Schroeder, J.J. Christensen, Factors affecting resistance of wheat to scab caused by Gibberella zeae, Phytopathology, 53, 1963, 831-838.

51. J. Chelkowski, H. Wisniewska, T. Adamski, P. Golinski, Z. Kaczmarek, M. Kostecki, J. Perkowski, M. Surma, Effects of Fusarium culmorum head blight on mycotoxin accumulation and yield traits in barley doubled haploids, Journal of Phytopathology, $148,2000,541-545$.

52. B.J. Blaney, R.L. Dodman, Production of zearalenone, deoxynivalenol, nivalenol, and acetylated derivated by Australian isolates of Fusarium graminearum and $F$. pseudograminearum in relation to source and culturing conditions, Australian Journal of Agricultural Research, 53, 2002, 1317-1326.

53. N. Magan, R. Hope, A. Colleate, E.S. Baxter, Relationship between growth and mycotoxin production by Fusarium species, biocides and environment, European Journal of Plant Pathology, 108, 2002, 685-690.

54. D.C. Hooker, A.W. Schaafsma, L. Tamburic-Ilincic, Using weather variables pre- and post-heading to predict deoxynivalenol content in winter wheat, Plant Disease, 86, 2002, 611-619.

55. A. Champeil, J.F. Fourbet, T. Doré, Influence of cropping system on Fusarium head blight and mycotoxin levels in winter wheat, Crop Protection. Sous presse, 2004.

56. L. Scott, S. Leath, W. Hagler, J. Murphy, Variation in Fusarium graminearum associated with wheat scab in north Carolina. In "National Fusarium Head Blight Forum. Chapter 1- Epidemiology and Disease Management", Michigan State University (USA), 1998, pp. 15.

57. M. Dusabenyagasani, R.C. Hamelin, J. Collin, D. Dostaler, Importance de l'interaction entre les cultivars de blé et les souches de Fusarium graminearum dans l'évaluation de la résistance à la fusariose de l'épi, Phytoprotection, 78(2), 1997, 53-60.

58. P. Pissinger, Fusarium infection of wheat seeds in the Vas province [Hungarian] (abstract), Novenyvedelem, 18, 1982, 83-85.

59. D. Caron, Fusarioses des épis. Sait-on prévoir leur développement ?, Perspectives Agricoles, 253, 2000, 56-62.

60. M.G. Cromey, S.C. Shorter, D.R. Lauren, K.I. Sinclair, Cultivar and crop management influences on fusarium head blight and mycotoxins in spring wheat (Triticum aestivum) in New Zealand, New Zealand Journal of Crop and Horticultural Science, 30, 2002, 235-247. 
1612 61. G. Bai, G. Shaner, Scab of wheat : Prospects for control, Plant Disease, 78(8), 1994, $1613 \quad 760-766$.

1614 62. P. Jenkinson, D.W. Parry, Isolation of Fusarium species from common broad-leaved 1615

68. F. Trail, D. Gadoury, R. Loranger, Environmental parameters of ascospore discharge

70. J.A. Clement, D. Parry, Stem-base disease and fungal colonisation of winter wheat

63. C.M. Messiaen, R. Cassini, Recherches sue les Fusarioses. IV- La systématique des

64. F. Rapilly, J.M. Lemaire, R. Cassini, Les Fusarioses. In "Les maladies des céréales 65. G. Le Henaff, B. Oste, E. Wilhem, A. Faure, J. Moinard, P. Lepoutre, O. Pillon, Bilan sanitaire 2001-2002 des céréales. Retour au sec et au calme pour des résultats moyens, Phytoma, 556, 2003, 22-26.

66. F. Trail, H. Xu, R. Loranger, D. Gadoury, Physiological and environmental aspects of ascospore discharge in Gibberella zeae (anamorph Fusarium graminearum), Mycologia, 94, 2002, 181-189.

67. T. Paulitz, Diurnal release of ascospores by Gibberella zeae in inoculated wheat plots, Plant Disease, 80, 1996, 674-678. in Gibberella zeae. In "National Fusarium Head Blight Forum. Chapter 1Epidemiology and Disease Management", Michigan State University (USA), 1998, pp. 11-13.

69. W.L. Gordon, The occurrence of Fusarium species in Canada. VI- Taxonomy and geographic distribution of Fusarium species on plants, insects, and fungi. Cité par Parry et al. 1995, Canadian Journal of Botany, 37, 1959, 257-290.

72. V.W.L. Jordan, E.C. Fielding, "Fusarium spp. on wheat. Cité par Parry, 1995," Long Ashton Research Station, 1988.

1644 73. C.H.A. Snijders, Systemic fungal growth of Fusarium culmorum in stems of winter wheat, Journal of Phytopathology, 129, 1990a, 133-140. 
74. T. Sieber, T.K. Risen, E. Müller, P.M. Fried, Endophytic fungi in four winter wheat cultivars (Triticum aestivum L.) differing in resistance against Stagonospora nodorum (Berk.) Cast. Et germ. = Septoria nodorum (berk.) Berk. Cité par Jenkinson, 1994b, Journal of phytopathology, 122, 1988, 289-306.

75. W.G.D. Fernando, J.D. Miller, W.L. Seaman, K. Seifert, T.C. Paulitz, Daily and seasonal dynamics of airborne spores of Fusarium graminearum and other Fusarium species sampled over wheat plots, Canadian Journal of Botany, 78, 2000, 497-505.

76. H.M. Hörberg, Patterns of splash dispersed conidia of Fusarium poae and Fusarium culmorum, European Journal of Plant Pathology, 108, 2002, 73-80.

77. F.J. Bannon, B.M. Cooke, Studies on dispersal of Septoria tritici pycnidiospores in wheat-clover intercrops, Plant Pathology, 47, 1998, 49-56.

78. B. Birzele, A. Meier, H. Hindorf, J. Krämer, H.W. Dehne, Epidemiology of Fusarium infection and deoxynivalenol content in winter wheat in the Rhineland, Germany, European Journal of Plant Pathology, 108, 2002, 667-673.

79. R.W. Stack, Gradients of Fusarium head blight in wheat along transects away from a concentrated source of Gibberella zeae ascospore inoculum. In "Proceedings of the 1997 National Fusarium Head Blight Foru,10-12 nov." St. Paul, Minn, 1997, pp. 60.

80. R. Bandyopadhyay, L.K. Mughogho, M.V. Satyanarayana, M.E. Kalisz, Occurrence of airborne spores of fungi causing grain mould over a sorghum crop, Mycological Research, 95(11), 1991, 1315-1320.

81. F.R. Sanderson, Fusarium diseases of cereals. VIII. Discharge and dispersal of ascospores of Calonectria nivalis, Transactions of the British Mycological Society, 55(1), 1970, 137-140.

82. C.T. Ingold, "Fungal spores: Their liberation and dispersal. Cité par Paulitz, 1996," Clarendon Press, Oxford, UK, 1971.

83. A.T. Tschanz, R.K. Horst, P.E. Nelson, The effect of environnement on sexual reproduction of Gibberella zeae, Mycologia, 68, 1976, 327-340.

84. H.Z. Ye, On the biology of the perfect stage of Fusarium graminearum Schw. Cité par Sutton, 1982, Acta Phytopatholigica Sinica, 7, 1980, 35-42.

85. www.syngenta.ca, 2002.

86. R.N. Strange, H. Smith, A fungal growth stimulant in anthers which predisposes wheat to attack by Fusarium graminearum, Physiological Plant Pathology, 1, 1971, 141-150. 
1679 87. J. Lacey, G.L. Bateman, C.J. Mirocha, Effects of infection time and moisture on development of ear blight and deoxynivalenol production by Fusarium spp. in wheat, Annals of Applied Biology, 134, 1999, 277-283.

88. K. Matsui, M. Yoshida, T. Ban, T. Komatsuda, N. Kawada, Role of male-sterile cytoplasm in resistance to barley yellow mosaic virus and Fusarium head blight in barley, Plant Breeding, 121, 2002, 237-240.

89. R.N. Strange, H. Smith, Effects of choline, betaine and wheat-germ extract on growth

90. A.H. Teich, Epidemiology of wheat (Triticum aestivum L.) scab caused by Fusarium spp. In "Fusarium: mycotoxins, taxonomy and pathogenicity", (Chelkowski, ed.), 1989, pp. 269-282.

91. B.D. McCallum, A. Tekauz, Influence of inoculation method and growth stage on Fusarium head blight in barley, Canadian Journal of Plant Pathology, 24, 2002, 77-80.

92. L.M. Reid, T. Woldemariam, X. Zhu, D.W. Stewart, A.W. Schaafsma, Effect of inoculaiton time and point of entry on disease severity in Fusarium graminearum,

93. M. Urban, S. Daniels, E. Mott, K. Hammond-Kosack, Arabidopsis is suceptible to the

94. Z. Kang, H. Buchenauer, Ultrastructural and immunocytochemical investigation of cereal ear blight fungal pathogens Fusarium graminearum and Fusarium culmorum,

95. W.M. Wanjiru, K. Zhensheng, H. Buchenauer, Importance of cell wall degrading

96. Z. Kang, H. Buchenauer, Studies on the infection process of Fusarium culmorum in wheat spikes: Degradation of host cell wall components and localization of trichothecene toxins in infected tissue, European Journal of Plant Pathology, 108, 2002, 653-660. 
1711 97. J.M. Sung, R.J. Cook, Effects of water potential on reproduction and spore

1712

1713

1714

1715

1716

1717

1718

1719

1720

1721

1722

1723

1724

1725

1726

1727

1728

1729

1730

1731

1732

1733

1734

1735

1736

1737

1738

1739

1740

1741

1742

germination by Fusarium roseum 'graminearum', 'culmorum', and 'avenaceum', Phytopathology, 71(5), 1981, 499-504.

98. R. Cassini, Influences des techniques de culture sur le développement des maladies des céréales. Chap. Méthodes de lutte culturale, génétique et biologique. In "La lutte contre les maladies des céréales", (C. ITCF, ed.), Versailles, 1973, pp. 17-34.

99. A.H. Teich, K. Nelson, Survey of Fusarium head blight and possible effects of cultural practices in wheat fields in Lambton County in 1983, Canadian Plant Disease Survey, 64(1), 1984, 11-13.

100. A.H. Teich, J.R. Hamilton, Effect of cultural practices, soil phosphorus, potassium, and $\mathrm{pH}$ on the incidence of Fusarium head blight and deoxynivalenol levels in wheat, Applied and Environmental Microbiology, 79(6), 1985, 1429-1431.

101. H. Krebs, D. Dubois, C. Kulling, H.R. Forrer, The effects of preceding crop and tillage on the incidence of Fusarium spp. and mycotoxin deoxynivalenol content in winter wheat grain [German] (abstract), Agrarforschung, 7, 2000, 264-268.

102. L. Manuca, Competition between predominant bacteria in the wheat rhizosphere and fusarium culmorum (Sm.) Sacc. in vitro (abstrat), I.C.C.P.T. Fundulea, 35, 1969, 765774.

103. K. Trolldenier, Maladie des céréales et nutrition des plantes, Revue de la Potasse, section 23, 1969, 1-16.

104. I. Coulomb, J. Caneill, H. Manichon, Comportement du sol au labour : méthode d'analyse et évaluation des conséquences de l'état initial du sol sur l'état transformé par le labour, Agronomie, 13, 1993, 45-56.

105. J. Guerif, G. Richard, C. Durr, J.M. Machet, S. Recous, J. Roger-Estrade, A review of tillage effects on crop residue management, seedbed conditions and seedling establishment, Soil \& Tillage Research, 61, 2001, 13-32.

106. D.C. Reicosky, Tillage-induced soil properties and chamber mixing effects on gas exchange. In "International soil tillage research organisation $16^{\text {th }}$ triennial conference", Vol. 1, Erica Maddock, Acacia Computing Services Pty Ltd, The University of Queensland Brisbane, Australia, 2003, pp. 117.

107. Y. Ben-Yephet, M. Reuven, A. Genizi, Effects of inoculum depth and density on Fusarium wilt in carnations, Phytopathology, 84(12), 1994, 1393-1398. 
1743

1744

1745

1746

1747

1748

1749

1750

1751

1752

1753

1754

1755

1756

1757

1758

1759

1760

1761

1762

1763

1764

1765

1766

1767

1768

1769

1770

1771

1772

1773

1774

1775

1776

108. G.L. Bateman, H. Coskun, Populations of Fusarium spp. in soil growing continuous winter wheat, and effects of long-term application of fertilizers and of straw incorporation, Mycological Research, 99(11), 1995, 1391-1394.

109. G.L. Bateman, G. Murray, R.J. Gutteridge, H. Coskun, Effects of method of straw disposal and depth of cultivation on populations of Fusarium spp. in soil and on brown foot rot in continuous winter wheat, Annals of Applied Biology, 132, 1998, 35 47.

110. M. Jalaluddin, J.F. Jenkyn, Effects of wheat crop debris on the sporulation and survival of Pseudocercosporella herpotrichoides, Plant Pathology, 45, 1996, 10521064.

111. D.J. Yarham, The effect on soil-borne diseases of changes in crop and soil management. In "Schippers B, gams Weds", Soil-borne Plant Pathogens, UK Academic Press, London, 1979, pp. 371-383.

112. B.S. Rodgers-Gray, M.W. Shaw, Substantial reductions in winter wheat diseases caused by addition of straw but not manure to soil, Plant Pathology, 49, 2000, 590599.

113. T.L.W. Carver, R.J. Zeyen, G.G. Ahlstrand, The relation between insoluble silicon and success or failure of attempted primary penetration by powdery mildew (Erysiphe graminis) germlings on barbley, Physiological and Molecular Plant Pathology, 31, 1987, 133-148.

114. R.R. Bélanger, P.A. Bowen, D.L. Ehret, J.G. Menzies, Soluble silicon: its role in crop and disease management of greenhouse crops, Plant Disease, 79(4), 1995, 329-336.

115. B.A. Summerell, L.W. Burgess, T.A. Klein, A.B. Pattison, Stubble management and the site of penetration of wheat by Fusarium graminearum group 1, Phytopathology, 80, 1990, 877-879.

116. M.L. Deadman, B.M. Cooke, Wheat disease and cereal-clover bicrops, Management Focus, 2, 1997, 15-19.

117. M.H. Leitch, P.D. Jenkins, Influence of nitrogen on the development of Septoria epidemics in winter wheat, Journal of Agricultural Science, 124, 1995, 361-368.

118. R.A. Martin, J.A. MacLeod, C. Caldwell, Influences of production inputs on incidence of infection by Fusarium species on cereal seed, Plant Disease, 75(8), 1991, 784-788.

119. M. Lemmens, K. Haim, H. Lew, P. Ruckenbauer, The effect of nitrogen fertilization on Fusarium head blight development and deoxynivalenol contamination in wheat, Journal of Phytopathology, 152, 2004, 1-8. 
1777

1778

1779

1780

1781

1782

1783

1784

1785

1786

1787

1788

1789

1790

1791

1792

1793

1794

1795

1796

1797

1798

1799

1800

1801

1802

1803

1804

1805

1806

1807

1808

1809

1810

120. M.T. Fauzi, T.C. Paulitz, The effect of plant growth regulators and nitrogen on Fusarium head blight of the spring wheat cultivar max, Plant Disease, 78, 1994, 289292.

121. R.W. Smiley, R.J. Cook, P. R.I., Fusarium foot rot of wheat and peas as influenced by soil applications of anhydrous ammonia and ammonia-potassium azide solutions, Phytopathology, 62, 1972, 86-91.

122. D.M. Huber, R.D. Watson, Nitrogen form and plant disease, Annuals review of phytopathology, 12, 1974, 139-165.

123. G. Lazarovits, Management of soil-borne plant pathogens with organic soil amendments: a disease control strategy salvaged from the past, Canadian Journal of Plant Pathology, 23, 2001, 1-7.

124. H.J.M. Loffler, E.B. Cohen, G.T. Oolbekkink, B. Schippers, Nitrite as a factor in the decline of Fusarium oxysporum f. sp. dianthi in soil supplemented with urea and ammonium chloride, Nertherland Journal of Plant Pathology, 92, 1986, 153-162.

125. M. Ciotola, P. Neumann, Role of post harvest and spring application of urea and Trichoderma reesii QM9414 on the development of Venturia inequalis. Cité par Teich, 1989. In "Mycolog. Society America and Canadian Phytopathol. Society", 1987.

126. B.K. Vaidehi, Effect of foliar application of urea on the behaviour of Helminthosporium hawaiiensis in the rhizophere of rice, Indian Journal of Mycology and Plant Pathology, 3, 1973, 81-85.

127. A.K. Rowaished, The influence of different forms of nitrogen on Fusarium root-rot disease of winter wheat seedlings, Phytopathology, 100, 1981, 331-339.

128. P.E. Onuorah, Effect of mineral nutrition on the Fusarium Brown foot-rot of wheat, Plant and Soil, (1), 1969, 99-104.

129. C.M. Messiaen, Richesse en sucre des tiges de maïs et verse parasitaire, Revue de Pathologie Végétale et d'Entomologie Agricole de France, 36, 1957, 209-213.

130. E. Kurek, J. Jaroszuk-Scisel, Rye (Secale cereale) growth promotion by Pseudomonas fluorescens strains and their interactions with Fusarium culmorum under various soil conditions, Biological Control, 26, 2003, 48-56.

131. C. Alabouvette, Y. Couteaudier, J. Louvet, Recherches sur la résistance des sols aux maladies. XI- Etude comparative du comportement des Fusarium spp. dans un sol résistant et un sol sensible aux fusarioses vasculaires enrichis en glucose, Agronomie, 5(1), 1985a, 63-68. 
1811

1812

1813

1814

1815

1816

1817

1818

1819

1820

1821

1822

1823

1824

1825

1826

1827

1828

1829

1830

1831

1832

1833

1834

1835

1836

1837

1838

1839

1840

1841

1842

1843

132. C. Alabouvette, Y. Couteaudier, J. Louvet, Recherches sur la résistance des sols aux maladies. XII- Activité respiratoire dans un sol résistant et un sol sensible aux fusarioses vasculaires enrichis en glucose, Agronomie, 1985b, 69-72.

133. J.C. Arthur, Wheat scab. Cité par Teich, 1989 et Parry et al. 1995, Indiana Agricultural Experimental Station Bulletin, 36, 1891, 129-132.

134. L. Couture, Réceptivité de cultivars de céréales de printemps à la contamination des graines sur inflorescence par les Fusarium spp., Canadian Journal of Plant Science, 62, 1982, 29-34.

135. M.G. Anderson, "Winter wheat disease survey 1985. Cité par Parry et al. 1995," Research Station Kentville, Nova Scotia, 1986, pp. 53-55.

136. E.W. Hanson, E.R. Ausemus, E.C. Stakman, Varietal resistance of spring wxeats to fusarial head blights. Cité par Teich and Hamilton, 1989, Phytopathology, 40, 1950, 902-914.

137. I. Bujold, T.C. Paulitz, O. Carisse, Effect of Microsphaeropsis sp. on the production of perithecia and ascospores of Gibberella zeae, Plant Disease, 85(9), 2001, 977-984.

138. H. Diamond, B.M. Cooke, Preliminary studies on biological control of the Fusarium ear blight complex of wheat, Crop Protection, 22, 2003, 99-107.

139. I. Bujold, O. Carisse, T.C. Paulitz, Effect of Microsphaeropsis sp. strain P130A on the field production of perithecia of Gibberella zeae on wheat residues. In "Canadian Workshop on Fusarium head blight", Manitoba, 1999, pp. 112-113.

140. M. Davanlou, A.M. Madsen, C.H. Madsen, J. Hockenhull, Parasitism of macroconidia, chlamydospores and hyphae of Fusarium culmorum by mycoparasitic Pythium species, Plant Pathology, 48, 1999, 352-359.

141. J.C. Zadoks, T.T. Chang, C.F. Knozak, A decimal code for the growth stages of cereals, Weed Research, 14, 1974, 415-421.

142. J. Liggitt, P. Jenkinson, D.W. Parry, The role of saprophytic microflora in the development of Fusarium ear blight of winter wheat caused by Fusarium culmorum, Crop Protection, 16(7), 1997, 679-685.

143. A. Mesterhazy, T. Bartok, Control of Fusarium head blight of wheat by fungicides and its effect on the toxin contamination of the grains, Pflanzenschutz-Nachrichten Bayer, 49(2), 1996, 181-198.

144. C.S. McLaughlin, M.H. Vaughan, L.M. Campbell, C.M. Wei, M.E. Stafford, B.S. Hansen, Inhibition of protein synthesis by trichothecenes. Cité par Eudes et al., 2000. 
In "Mycotoxins in human and animal health", (P. F. S. Pathotox, ed.), Rodricks, J.V., Hesseltine, C.W., Mehlman, M.A., 1977.

145. F. Eudes, A. Comeau, S. Rioux, J. Collin, Phytotoxicité de huit mycotoxines associées à la fusariose de l'épi chez le blé, Canadian Journal of Plant Pathology, 22, 2000, 286292.

146. E. Young, Fusariose de l'épi sur blé tendre. Le précédent et le travail du sol sont déterminants, Cultivar, 506, 2001, 38-41.

147. C.H.A. Snijders, J. Perkowski, Effects of head blight caused by Fusarium culmorum on toxin content and weight of wheat kernels, Phytopathology, 80, 1990e, 566-570.

148. R.C. Sinha, M.E. Savard, Concentration of deoxynivalenol in single kernels and various tissues of wheat heads, Canadian Journal of Plant Pathology, 19, 1997, 8-12.

149. M.E. Savard, R.C. Sinha, W.L. Seaman, G. Fedak, Sequential distribution of the mycotoxin deoxynivalenol in wheat spikes after inoculation with Fusarium graminearum, Canadian Journal of Plant Pathology, 22, 2000, 280-285.

150. W.C.A. Gelderblom, K. Jaskiewicz, W.F.O. Marasas, P.G. Thiel, R.M. Horak, R.M. Vleggaar, N.P.J. Kriek, Fumonisins: novel mycotoxins with cancer-promoting activity producted by Fusarium moniliforme, Applied and Environmental Microbiology, 54(7), 1988, 1806-1811.

151. J.C. Wolf, J.R. Lieberman, C.J. Mirocha, Inhibition of F-2 (Zearalenone) biosynthesis and perithecium production of Fusarium roseum 'Graminearum', Phytopathology, 62, 1972, 937-939.

152. J.C. Wolf, C.J. Mirocha, Regulations of sexual reproduction in Gibberella zeae (Fusarium roseum 'Graminearum') by F-2 (Zearalenone), Canadian Journal of Microbiology, 19, 1973, 725-734.

153. J.C. Wolf, C.J. Mirocha, Control of sexual reproduction in Gibberella zeae (Fusarium roseum 'Graminearum'), Applied and Environmental Microbiology, 33(3), 1977, 546550.

154. R. Ioos, A. Faure, Fusariose des épis, mycotoxines et traitements fongicides, Phytoma, $539,2001,56-63$.

155. C.M. Placinta, J.P.F. D'Mello, A.M.C. Macdonald, A review of worldwide contamination of cereal grains and animal feed with Fusarium mycotoxins, Animal Feed Science and Technology, 78, 1999, 21-37.

156. A.W. Schaafsma, L. Tamburic-Ilincic, J.D. Miller, The effect of agronomic practice on the accumulation of deoxynivalenol (DON) in winter wheat fields in Ontario, 
1996-97. In "National Fusarium Head Blight Forum. Chapter 1- Epidemiology and Disease Management", Michigan State University (USA), 1998, pp. 7-9.

157. E. Jenny, A. Hecker, P. Kessler, C. Kulling, H.R. Forrer, Cereal fusarioses: varietal resistance and toxin contents [German] (Abstract), Agrarforschung, 7, 2000, 270-273.

158. E. Young, Itinéraire cultural blé. Ce qui favorise les mycotoxines, Cultivar, 539, 2002, 52.

159. C.J. Mirocha, H.K. Abbas, C.E. Windels, W. Xie, Variation in deoxynivalenol, 15acetyldeoxynivalenol, 3-acetyldeoxynivalenol and zearalenone production by Fusarium graminearum isolates, Applied and Environmental Microbiology, 55(5), 1989, 1315-1316.

160. J. Perkowski, A. Pavlova, A. Srobarova, J. Stachowiak, P. Golinski, Group B trichothecenes biosynthesis in wheat cultivars after heads inoculation with Fusarium culmorum isolates (abstract), Biologia, 57, 2002, 765-771.

161. B. Bakan, C. Giraud-Deville, L. Pinson, D. Richard-Molard, E. Fournier, Y. Brygoo, Identification by PCR of Fusarium culmorum strains producing large and small amounts of deoxynivalenol, Applied and Environmental Microbiology, 68, 2002, $5472-5479$.

162. Y.Z. Jin, T. Yoshizawa, Relationship between the incidence of mycotoxigenic Gibberella zeae (Fusarium graminearum) in crop fields and the occurence of trichothecenes in wheat [Japanese] (abstract), Mycotoxins, 40, 1994, 39-42.

163. H. Hestbjerg, S. Elmholt, K.F. Nielsen, G. Felding, The ecology of toxin producing fungi [Danish] (abstract). In "17th Danish Plant Protection Conference II, Site-specific crop protection, decision support, pests and diseases, ear blight", Denmark, 2000.

164. H. Hestbjerg, G. Felding, S. Elmholt, Fusarium culmorum infection of barley seedlings: correlation between aggressiveness and deoxynivalenol content, Journal of Phytopathology, 150, 2002, 308-312.

165. P. Jennings, M. Coates, J.A. Turner, P. Nicholson, Distribution of deoxynivalenol/nivalenol producing isolates of Fusarium culmorum and $F$. graminearum in England and Wales (abstract), Aspects of Applied Biology, 2003.

166. J.P. Carter, H.N. Rezanoor, D. Holden, A.E. Desjardins, R.D. Plattner, P. Nicholson, Variation in pathogenicity associated with the genetic diversity of Fusarium graminearum, European Journal of Plant Pathology, 108, 2002, 573-583.

167. A. Mesterhazy, Breeding wheat for resistance to Fusarium graminearum and Fusarium culmorum, Z. Pflanzenzüchtg - Plant Breeding, 91, 1983, 295-311. 
1912

168. C. ShouXi, G. Kleijer, Effects of Fusarium metabolites on growth of callus and seedling in triticale (abstract), Acta Prataculturae Sinica, 10, 2001, 78-85.

169. S. Marin, N. Magan, J. Serra, A.J. Ramos, R. Canela, V. Sanchis, Fumonisin B production and growth of Fusarium moniliforme and Fusarium proliferatum on maize, wheat, and barley grain, Journal of Food Science, 64(5), 1999, 921-924.

170. W.L. Casale, L.P. Hart, Inhibition of protein synthesis in maize by trichothecene mycotoxins, Abstract, Phytopathology, 76, 1986, 1144.

171. A.E. Desjardins, R.H. Proctor, G. Bai, S.P. McCormik, G. Shaner, G. Buechley, T.M. Hohn, Reduced virulence of trichothecene-nonproducing mutants of Gibberella zeae in wheat field tests, Molecular Plant-Microbe Interactions, 9(9), 1996, 775-781.

172. L.F. Chen, Y.L. Song, Y.G. Xu, Variation in the concentrations of deoxynivalenol in the spikes of winter wheat infected by Fusarium graminearum Schw [Chinese] (abstract), Acta Phytopatholigica Sinica, 26, 1996, 25-28.

173. A. Mesterhazy, Role of deoxynivalenol in aggressiveness of Fusarium graminearum and F. culmorum and in resistance to Fusarium head blight, European Journal of Plant Pathology, 108, 2002, 675-684.

174. R.H. Proctor, A.E. Desjardins, S.P. McCormick, R.D. Plattner, N.J. Alexander, D.W. Brown, Genetic analysis of the role of trichothecene and fumonisin mycotoxins in the virulence of Fusarium, European Journal of Plant Pathology, 108, 2002, 691-698.

175. F. Eudes, A. Comeau, S. Rioux, J. Collin, Impact of trichothecenes on Fusarium head blight (Fusarium graminearum) development in spring wheat (Titicum aestivum), Canadian Journal of Plant Pathology, 23, 2001, 318-322.

176. A.H. Teich, L. Shugar, A. Smid, Soft white winter wheat cultivar field-resistance to scab and deoxynivalenol accumulation, Cereal Research Communications, 15, 1987, 109-114.

177. C.H.A. Snijders, Fusarium head blight and mycotoxin contamination of wheat, a review, Nertherland Journal of Plant Pathology, 96, 1990b, 187-198.

178. W. Liu, W. Langseth, H. Skinnes, O.N. Elen, L. Sundheim, Comparison of visual head blight ratings, seed infection levels, and deoxynivalenol production for assessment of resistance in cereals inoculated with Fusarium culmorum, European Journal of Plant Pathology, 103, 1997, 589-595.

179. C. Lamper, J. Téren, T. Bartok, R. Komoroczy, A. Mesterhazy, F. Sagi, Predicting DON contamination in Fusarium-infected wheat grains via determination of the ergosterol content, Cereal Research Communications, 28(3), 2000, 337-344. 
1946

1947

1948

1949

1950

1951

1952

1953

1954

1955

1956

1957

1958

1959

1960

1961

1962

1963

1964

1965

1966

1967

1968

1969

1970

1971

1972

1973

1974

1975

1976

1977

1978

1979

180. J. Grabarkiewicz-Szczesna, E. Foremska, M. Kostecki, P. Golinski, J. Chelkowski, Trichothecenes accumulation in kernels of corn inoculated with Fusarium poae (Peck) Wollenw, Nahrung, 43, 1999, 330-332.

181. J.F. Fourbet, L. Malmauret, T. Doré, P. Verger, "Impact du mode de conduite des cultures sur la qualité agronomique et toxicologique du blé. Application à l'agriculture biologique," Rep. No. 99-36, Convention MAP/INRA, 2001.

182. S.L. Walker, S. Leath, W.M. Hagler, J.P. Murphy, Variation among isolates of Fusarium graminearum associated with Fusarium head bligh in north Carolinia, Plant Disease, 85(4), 2001, 404-410.

183. B. Cahagnier, Les mycotoxines des céréales. In "Mycotoxines : un prochain enjeu de sécurité alimentaire ?" (CERAAF, ed.), 2002, pp. 18-24.

184. A. Devaux, La fusariose de l'épi du blé, Agriculture (Montréal), 44, 1988, 8 et 25.

185. C.H.A. Snijders, The inheritance of resistance to head blight caused by Fusarium culmorum in winter wheat, Euphytica, 50, 1990d, 11-18.

186. Y.J. Yu, Monosomic analysis for scab resistance and yield components in wheat cultivar Soo-mo 3, Cereal Research Communications, 10(3-4), 1982, 185-189.

187. F.L. Kolb, G.H. Bai, G.J. Muehlbauer, J.A. Anderson, K.P. Smith, G. Fedak, Host plant resistance genes for fusarium head blight : mapping and manipulation with molecular markers, Crop Science, 41(3), 2001, 611-619.

188. L. Gervais, F. Dedryver, J.Y. Morlais, V. Bodusseau, S. Negre, M. Bilous, C. Groos, M. Trottet, Mapping of quantitative trait loci for field resistance to Fusarium head blight in an European winter wheat, Theoretical and Applied Genetics, 106, 2003, 961-970.

189. Z.Z. Liu, Z.Y. Wang, Improved scab resistance in China : sources of resistance and problems. Cité par Ban, 2000 et Rudd, 2001. In "Wheat for the non-traditional warm areas, international conference" (S. DA, ed.), CIMMYT publication, Mexico, 1991, pp. 178-188.

190. C. Pritsch, C.P. Vance, W.R. Bushnell, D.A. Somers, T.M. Hohn, G.J. Muehlbauer, Systemic expression of defense response genes in wheat spikes as a response to Fusarium graminearum infection, Physiological and Molecular Plant Pathology, 58, 2001, 1-12.

191. C.A. Urrea, R.D. Horsley, B.J. Steffenson, P.B. Schwarz, Heritability of Fusarium head blight resistance and deoxynivalenol accumulation from barley accession CIho 4196, Crop Science, 42, 2002, 1404-1408. 
1980

1981

1982

1983

1984

1985

1986

1987

1988

1989

1990

1991

1992

1993

1994

1995

1996

1997

1998

1999

2000

2001

2002

2003

2004

2005

2006

2007

2008

2009

2010

2011

2012

2013

192. A. Mesterhazy, T. Bartok, C.G. Mirocha, R. Komoroczy, Nature of wheat resistance to Fusarium head blight and the role of deoxynivalenol for breeding, Plant Breeding, 118, 1999, 97-110.

193. L.P. Hart, J.J. Pestka, M.T. Liu, Effect of kernel development and wet periods on production of deoxynivalenol in wheat infected with Gibberella zeae, Phytopathology, 74, 1984, 1415-1418.

194. H. Buerstmayr, M. Lemmens, G. Patschka, H. Grausgruber, P. Ruckenbauer, Head blight (Fusarium spp.) resistance of wheat cultivars registered in Australia. Cité par Ruckenbauer, 2001, Die Bodenkultur, 47, 1996b, 183-190.

195. M. Nakagawa, Studies on ear-scab resistance of wheat plants. 2. genetical factors affecting on the inheritance of ear-scab disease of wheat plants. Cité par Teich, 1989, Jap. J. Breeding, 5, 1955.

196. S. Hakimi, J. Liang, Y. Wu, C. Rosenberger, S. Castro, D. Shah, Gene therapy for plants. Cité par Ban, 2000, Cereal Research Communications, 25, 1997, 745-747.

197. C. Pritsch, W.R. Bushnell, D.A. Somers, G.J. Muehlbauer, C.P. Vance, Fusarium graminearum infection on wheat spikes: early events. In "National Fusarium Head Blight Forum. Chapter 1- Epidemiology and Disease Management", Michigan State University (USA), 1998, pp. 5.

198. W.P. Chen, P.D. Chen, D.J. Liu, R. Kynast, B. Friebe, R. Velazhahan, S. Muthukrishnan, B.S. Gill, Development of wheat scab symptoms is delayed in transgenic wheat plants that constitutively express a rice thaumatin-like protein gene, Theoretical and Applied Genetics, 99, 1999, 755-760.

199. L.S. Dahleen, P.A. Okubara, A.E. Blechl, Transgenic approaches to combat Fusarium head blight in wheat and barley, Crop Science, 41, 2001, 628-637.

200. T. Taira, T. Ohnuma, T. Yamagami, Y. Aso, M. Ishiguro, I. M., Antifungal activity of rye (Secale cereale) seed chitinases: the different binding manner of class I and class II chitinases to the fungal cell walls, Bioscience Biotechnology and Biochemistry, 66, 2002, 970-977.

201. G. Rebmann, F. Mauch, R. Dudler, Sequence of a wheat cDNA encoding a pathogeninduced thaumatin-like protein. Cité par Dahleen, 2001, Plant Mol. Bio., 17, 1991, 283-285.

202. A.I. Pekkarinen, B.L. Jones, Trypsin-like proteinase produced by Fusarium culmorum grown on grain proteins, Journal of Agricultural and Food Chemistry, 50, 2002, 38493855 . 
2014

2015

2016

2017

2018

2019

2020

2021

2022

2023

2024

2025

2026

2027

2028

2029

2030

2031

2032

2033

2034

2035

2036

2037

2038

2039

2040

2041

2042

2043

2044

2045

2046

2047

203. A.I. Pekkarinen, T.H. Sarlin, A.T. Laitila, A.I. Haikara, B.L. Jones, Fusarium species synthesize alkaline proteinases in infested barley, Journal of Cereal Science, 37, 2003a, 349-356.

204. A.I. Pekkarinen, B.L. Jones, Purification and identification of barley (Hordeum vulgare L.) proteins that inhibit the alkaline serine proteinases of Fusarium culmorum (abstract), Journal of Agricultural and Food Chemistry, 51, 2003b, 1710-1717.

205. M. Mohammadi, H. Kazemi, Changes in peroxidase and polyphenol oxidase activities in susceptible and resistant wheat heads inoculated with Fusarium graminearum and induced resistance, Plant Science, 162, 2002, 491-498.

206. J. Duvick, Prospects for reducing fumonisin contamination of maize through genetic modification (abstract), Environmental Health Perspectives, 109, 2001, 337-342.

207. R.A.d. Maagd, D. Bosch, W. Stiekema, Bacillus thuringiensis toxin-mediated insect resistance in plants, Trends in Plant Science, 4, 1999, 9-13.

208. C.H. Zhong, D.J. Ellar, A. Bishop, C. Johnson, S.S. Lin, E.R. Hart, Characterization of a Bacillus thuringiensis delta-endotoxin which is toxic to insects in three orders (abstract), Journal of Invertebrate Pathology, 76, 2000, 131-139.

209. R. Mitterbauer, G. Adam, Saccharomyces cerevisae and Arabidopsis thaliana: Useful model systems for the identification of molecular mechanisms involved in resistance of plants to toxins, European Journal of Plant Pathology, 108, 2002, 699-703.

210. E. Siranidou, Z. Kang, H. Buchenauer, Studies on symptom development, phenolic compounds and morphological defence responses in wheat cultivars differing in resistance to Fusarium head blight, Journal of Phytopathology, 150, 2001, 200-208.

211. Anonyme, "Protection against trichothecene mycotoxins. Cité par Wang and Miller, 1988 et Eudes, 1998," National Academy Press. Washington D.C. v, Washington D.C, 1983, pp. 227.

212. Y. Castonguay, L. Couture, Epidémiologie de la contamination des grains de céréales par les Fusarium spp., Canadian Journal of Plant Pathology, 5, 1983, 222-228.

213. J.D. Miller, J.C. Young, H.L. Trenholm, Fusarium toxins in field corn. I- Time course of fungal growth and production of deoxynivalenol and other mycotoxins, Canadian Journal of Botany, 61, 1983, 3080-3087.

214. J.D. Miller, J.C. Young, D.R. Sampson, Deoxynivalenol and Fusarium head blight resistance in spring cereals, Journal of Phytopathology, 113, 1985a, 359-367.

215. J.D. Miller, J.C. Young, Deoxynivalenol in an experimental Fusarium graminearum infection of wheat, Canadian Journal of Plant Pathology, 7, 1985b, 132-134. 
216. J.D. Miller, P.G. Arnison, Degradation of deoxynivalenol by suspension cultures of the Fusarium head blight resistant wheat cultivar Frontana, Canadian Journal of Plant Pathology, 8, 1986, 147-150.

217. R.W. Stack, Return of an old problem: Fusarium head blight of small grains, Plant Health Progress, 2000.

218. X.Y. Li, Z.S. Wu, Studies on the relationship between choline concentration in flowering spikes and resistance to scab among bread wheat varieties. Cité par Eudes, 1998, Acta Agr. Sinica, 20, 1994, 176-185.

219. Y.P. Wang, Y.Q. Liu, L. Shi, N.S. Pan, Z.L. Chen, SOD activity of wheat varieties with different resistance to scab (abstract), Acta Phytophysiologica Sinica, 19(4), $1993,353-358$.

220. P.A. Okubara, A.E. Blechl, S.P. McCormick, N.J. Alexander, R. Dill-Macky, T.M. Hohn, Engineering deoxynivalenol metabolism in wheat through the expression of a fungal trichothecene acetyltransferase gene, Theoretical and Applied Genetics, 106, 2002, 74-83.

221. R.W. Stack, J.D. Rasmussen, Ferulic acid as a factor in resistance in wheat to Fusarium head blight, Phytopathology, 85, 1995, 1046.

222. J.G. Horsfall, A.E. Dimond, Interactions of tissue sugar, growth substances and disease susceptibility, Zeitschrift fuer Pflanzenkrankheiten, 64(7-10), 1957, 415-421.

223. T. Aoki, K. O'Donnell, Morphological and molecular characterization of Fusarium pseudograminearum sp. nov., formerly recognized as the Group 1 population of Fusarium graminearum, Mycologia, 91(4), 1999a, 597-609.

224. T. Aoki, K. O'Donnell, Morphological characterization of Gibberella coronicola sp. nov., obtained through mating experiments of Fusarium pseudograminearum, Mycoscience, 40, 1999b, 443-453.

225. A.H. Wearing, L.W. Burgess, Water potential and the saprophytic growth of Fusarium roseum "graminearum", Soil Biology and Biochemistry, 11, 1979, 661-667. 
2076 Figure 1: Symptoms of Fusarium head blight on the external surface of wheat ear glumes. 2077

2078

2079

2080

2081

2082

2083

2084

2085

2086

2087

2088

2089

2090

2091 
2092 Table 1: Data on environmental conditions for the production of macroconidia and ascospores in the laboratory, 2093 according to species. Two natural populations of $F$. graminearum can be identified: Group 1 (or $F$. 2094 pseudograminearum), normally associated with the diseased crowns of host plants, which do not form perithecia 2095 in culture and form such structures only rarely in nature, and Group 2, associated with diseased of aerial plant 2096 parts, which do form perithecia- $[2,223,224]$. 


\begin{tabular}{|c|c|c|c|c|c|}
\hline Stage & Species & $\begin{array}{l}\text { Determinant } \\
\text { factors }\end{array}$ & Range & \begin{tabular}{|l} 
Optimal \\
value
\end{tabular} & References \\
\hline \multirow{9}{*}{$\begin{array}{l}\text { Mycelial } \\
\text { growth }\end{array}$} & \multirow{6}{*}{$\begin{array}{l}F . \quad \text { graminearum } \\
\text { group } 2 \text { (aerial) }\end{array}$} & $\begin{array}{l}\text { Pressure } \\
\text { Humidity }\end{array}$ & \multicolumn{2}{|l|}{$\begin{array}{l}>-9 \text { bars } \\
>94 \% \mathrm{RH}\end{array}$} & [75] (on maize grains) \\
\hline & & Pressure & $>-12$ bars & -2 bars & [225] (on agar) \\
\hline & & Temperature & 4 to $32^{\circ} \mathrm{C}$ & $28^{\circ} \mathrm{C}$ & {$[47]$} \\
\hline & & $\begin{array}{l}\text { Pressure, } \\
\text { Temperature }\end{array}$ & \multicolumn{2}{|c|}{$\begin{array}{l}\text { At }-10 \text { bars, } \mathrm{T} \text {. optim } 20^{\circ} \mathrm{C} \\
\text { At }-28 \text { bars, T. optim } 30^{\circ} \mathrm{C} \\
\text { At }-55 \text { bars, T. optim } 35^{\circ} \mathrm{C}\end{array}$} & {$[16]$} \\
\hline & & $\begin{array}{l}\text { Temperature } \\
\text { Pressure }\end{array}$ & \multicolumn{2}{|c|}{$\begin{array}{l}20 \text { to } 30^{\circ} \mathrm{C} \\
-10 \text { to }-28 \text { bars }\end{array}$} & $\begin{array}{l}\text { [23] (on osmotically } \\
\text { adjusted agar) }\end{array}$ \\
\hline & & \multicolumn{3}{|c|}{$\begin{array}{l}\text { Accelerated by alternate periods of rainfall and } \\
\text { drought before ear emergence }\end{array}$} & {$[59]$} \\
\hline & \multirow[b]{2}{*}{ F. culmorum } & $\begin{array}{l}\text { Temperature } \\
\text { Pressure }\end{array}$ & \multicolumn{2}{|l|}{$\begin{array}{l}20 \text { to } 30^{\circ} \mathrm{C} \\
-8 \text { to }-14 \text { bars }\end{array}$} & $\begin{array}{l}\text { [23] (on osmotically } \\
\text { adjusted agar) }\end{array}$ \\
\hline & & $\begin{array}{l}\text { Pressure } \\
\text { Temperature }\end{array}$ & \multicolumn{2}{|c|}{$\begin{array}{l}\text { At }-8 \text { bars, T. optim } 20^{\circ} \mathrm{C} \\
\text { At }-14 \text { bars T. optim } 30^{\circ} \mathrm{C} \\
\text { At }-28 \text { bars, T. optim } 38^{\circ} \mathrm{C} \\
\text { Maximum growth at } 25^{\circ} \mathrm{C}\end{array}$} & {$[16]$} \\
\hline & M. nivale & Temperature & 0 to $28-32^{\circ} \mathrm{C}$ & $18-20^{\circ} \mathrm{C}$ & {$[11,16]$} \\
\hline \multirow{3}{*}{$\begin{array}{l}\text { Initiation } \\
\text { perithecia }\end{array}$} & \multirow{3}{*}{$\begin{array}{l}F . \quad \text { graminearum } \\
\text { group } 2 \text { (aerial) } \\
\text { F. roseum }\end{array}$} & Light & \multicolumn{2}{|c|}{$\begin{array}{l}\text { Requires low intensity of UV } \\
\text { light }(300-320<390 \mathrm{~nm})\end{array}$} & $\begin{array}{l}\text { [83], with conflicting } \\
\text { results obtained by [35]. }\end{array}$ \\
\hline & & & \multicolumn{2}{|c|}{ Depends on the strain } & {$[35,71]$} \\
\hline & & Depends on $\mathrm{h}$ & umidity and rain in $\mathrm{s}$ & pring & {$[59]$} \\
\hline \multirow{4}{*}{\multicolumn{2}{|c|}{$\begin{array}{l}\text { Production de perithecia } \\
\text { F. graminearum group } 2 \text { (aerial) }\end{array}$}} & Temperature & 5 to $35^{\circ} \mathrm{C}$ & $29^{\circ} \mathrm{C}$ & {$[2,16]$} \\
\hline & & Temperature & 15 to $31^{\circ} \mathrm{C}$ & $29^{\circ} \mathrm{C}$ & {$[83]$} \\
\hline & & Pressure & $\begin{array}{l}<-50 \text { bars, poor } \\
\text { from }-5 \text { bars }\end{array}$ & -1.5 bars & $\begin{array}{l}\text { [97] (on osmotically } \\
\text { adjusted agar) }\end{array}$ \\
\hline & & \multicolumn{3}{|c|}{ Depends on light } & {$[68]$} \\
\hline $\begin{array}{l}\text { Production of } \\
\text { ascospores }\end{array}$ & \begin{tabular}{|l|}
$\begin{array}{l}\text { F. } \\
\text { group } 2 \text { (aminearial) }\end{array}$ \\
\end{tabular} & $\begin{array}{l}\text { Temperature } \\
\text { Light }\end{array}$ & $\begin{array}{l}13 \text { to } 33^{\circ} \mathrm{C} \\
\text { UV light required }\end{array}$ & $25-28^{\circ} \mathrm{C}$ & {$[2,16]$} \\
\hline \multirow{2}{*}{$\begin{array}{l}\text { Production of } \\
\text { spores }\end{array}$} & M. nivale & Temperature & $<16-18^{\circ} \mathrm{C}$ & 6 à $8^{\circ} \mathrm{C}$ & {$[64]$} \\
\hline & Fusarium & $\begin{array}{l}\text { Temperature } \\
\text { Humidity }\end{array}$ & \multicolumn{2}{|c|}{$\begin{array}{l}\text { Around } 10^{\circ} \mathrm{C} \\
\text { Around } 80 \% \text { humidity } \\
\end{array}$} & {$[64]$} \\
\hline \multirow{10}{*}{$\begin{array}{l}\text { Production of } \\
\text { macroconidia }\end{array}$} & \multirow{4}{*}{$\begin{array}{l}F . \quad \text { graminearum } \\
\text { group } 2 \text { (aerial) }\end{array}$} & Temperature & \multicolumn{2}{|c|}{$\begin{array}{l}28 \text { to } 32^{\circ} \mathrm{C} \\
\text { None if } \mathrm{T}^{\circ}<16^{\circ} \mathrm{C} \text { or } \mathrm{T}^{\circ}>36^{\circ} \mathrm{C}\end{array}$} & {$[83]$} \\
\hline & & Temperature & $16-36^{\circ} \mathrm{C}$ & $28-32^{\circ} \mathrm{C}$ & [47] \\
\hline & & Pressure & $\max <-50$ bars & $\begin{array}{|lll|}-1.4 & \text { to } & -3 \\
\text { bars } & & \end{array}$ & $\begin{array}{l}\text { [97] (on osmotically } \\
\text { adjusted agar) }\end{array}$ \\
\hline & & $\begin{array}{l}\text { Temperature } \\
\text { Pressure }\end{array}$ & \multicolumn{2}{|l|}{$\begin{array}{l}20 \text { to } 30^{\circ} \mathrm{C} \\
-10 \text { to }-28 \text { bars } \\
\end{array}$} & \multirow{2}{*}{$\begin{array}{l}\text { [23] (on osmotically } \\
\text { adjusted agar) }\end{array}$} \\
\hline & \multirow{2}{*}{ F. culmorum } & $\begin{array}{l}\text { Temperature } \\
\text { Pressure }\end{array}$ & \multicolumn{2}{|l|}{$\begin{array}{l}20 \text { to } 30^{\circ} \mathrm{C} \\
-8 \text { to }-14 \text { bars } \\
\end{array}$} & \\
\hline & & Pressure & $\begin{array}{l}\text { Max between }-15 \\
\text { and }-60 \text { bars }\end{array}$ & -15 bars & $\begin{array}{l}\text { [97] (on osmotically } \\
\text { adjusted agar) }\end{array}$ \\
\hline & $\begin{array}{l}F . \quad \text { graminearum } \\
\text { group } 1 \text { (soil) } \\
\text { F. avenaceum } \\
\end{array}$ & Pressure & $\begin{array}{l}\text { Max between }-15 \\
\text { and }-60 \text { bars }\end{array}$ & -15 bars & $\begin{array}{l}{[97] \text { (on osmotically }} \\
\text { adjusted agar) }\end{array}$ \\
\hline & \multirow[b]{2}{*}{ F. roseum } & Temperature & $>10^{\circ} \mathrm{C}$ & 25 to $30^{\circ} \mathrm{C}$ & \\
\hline & & $\begin{array}{l}\text { Light } \\
\text { Humidity }\end{array}$ & \multicolumn{2}{|c|}{$\begin{array}{l}\text { UV light required } \\
\text { RH of about } 100 \% \\
\text { Favoured by water stress }\end{array}$} & {$[16]$} \\
\hline & M. nivale & Temperature & 1 to $16^{\circ} \mathrm{C}$ & 6 to $8^{\circ} \mathrm{C}$ & {$[16]$} \\
\hline
\end{tabular}


Table 2: Spectrum of infection of weeds by Fusarium species. M: Monocotyledonous, g: grasses, D

2102 Dicotyledonous.

\begin{tabular}{|c|c|c|c|c|c|}
\hline \multirow{2}{*}{$\begin{array}{l}\text { Weed host } \\
\text { Family }\end{array}$} & & & Fusarium & \multirow{2}{*}{ Site and form } & \multirow{2}{*}{ Reference } \\
\hline & Latin name & Common name & Species & & \\
\hline Poaceae Mg & Agropyron & Wheatgrass & Not indicated & Not indicated & [85] \\
\hline Liliaceae M & Allium & Garlic & $\begin{array}{l}F . \text { avenaceum, } F \text {. } \\
\text { culmorum, } \\
\text { F. graminearum }\end{array}$ & Not indicated & [64] \\
\hline Poaceae Mg & $\begin{array}{l}\text { Alopecurus } \\
\text { myosuroides Huds. }\end{array}$ & Blackgrass & F. roseum & In the seed & {$[48]$} \\
\hline Poaceae Mg & Avena fatua $\mathrm{L}$. & Wild oats & F. roseum & $\begin{array}{l}\text { Lesion, spores on } \\
\text { leaves and seeds }\end{array}$ & {$[48]$} \\
\hline Chenopodiaceae D & Beta vulgaris & Wild beet & F. culmorum & Stem base & {$[62]$} \\
\hline Cruciferae D & $\begin{array}{l}\text { Capsella bursa- } \\
\text { pastoris L. }\end{array}$ & Shepherd's purse & $\begin{array}{l}F . \text { avenaceum, } F . \\
\text { culmorum, } F . \text { poae, } \\
F . \text { sambucinum }\end{array}$ & Stem base & {$[62]$} \\
\hline Compositae D & Cirsium arvense L. & Thistle & F. avenaceum & Stem base & {$[62]$} \\
\hline Poaceae Mg & Dactylis L. & Cocksfoot & F. roseum & $\begin{array}{l}\text { Lesion on straw, } \\
\text { stem base, increase } \\
\text { with } \mathrm{N}\end{array}$ & {$[14,48]$} \\
\hline Poaceae Mg & $\begin{array}{l}\text { Echinochloa crus- } \\
\text { galli L. }\end{array}$ & Barnyardgrass & Not indicated & Not indicated & {$[85]$} \\
\hline Poaceae Mg & Festuca & Fescue & $F$. roseum & $\begin{array}{l}\text { Stem base, increase } \\
\text { with N }\end{array}$ & {$[14]$} \\
\hline Rubiaceae D & Galium aparine L. & Cleavers & $\begin{array}{l}\text { F. avenaceum, } F \text {. } \\
\text { culmorum, } F \text {. poae }\end{array}$ & Stem base & {$[62]$} \\
\hline Poaceae Mg & $\begin{array}{l}\text { Lolium multiflorum } \\
\text { L. }\end{array}$ & Ryegrass & F. roseum & $\begin{array}{l}\text { Lesion on straw, } \\
\text { stem base, increase } \\
\text { with } \mathrm{N}\end{array}$ & {$[14,48]$} \\
\hline Compositae D & Matricaria spp. & Mayweed & $\begin{array}{l}F . \text { avenaceum, } F . \\
\text { culmorum, } \\
F . \text { graminearum, } F . \text { poae, } \\
F . \text { sambucinum }\end{array}$ & Stem base & [62] \\
\hline Ranunculaceae D & Ranunculus acris & $\begin{array}{l}\text { Common } \\
\text { buttercup }\end{array}$ & $\begin{array}{l}F \text {. avenaceum, } F \text {. } \\
\text { culmorum, } F \text {. poae }\end{array}$ & Stem base & {$[62]$} \\
\hline Ranunculaceae D & $\begin{array}{l}\text { Ranonculus repens } \\
\text { L. }\end{array}$ & $\begin{array}{l}\text { Creeping } \\
\text { buttercup }\end{array}$ & $\begin{array}{l}F . \text { avenaceum, } F \text {. } \\
\text { culmorum }\end{array}$ & Stem base & [62] \\
\hline Polygonaceae D & Rumex obtusifolius & Dock & $\begin{array}{l}F \text {. avenaceum, } F \text {. } \\
\text { culmorum }\end{array}$ & Stem base & {$[62]$} \\
\hline Compositae D & Senecio vulgaris L. & Groundsel & $\begin{array}{l}F \text {. avenaceum, } F \text {. } \\
\text { culmorum }\end{array}$ & Stem base & {$[62]$} \\
\hline Caryophyllaceae D & Spergula arvensis L. & Corn spurrey & F. sambucinum & Stem base & [62] \\
\hline Carophyllaceae D & Stellaria media $\mathrm{L}$. & Chickweed & F. avenaceum & Stem base & [62] \\
\hline Fabaceae D & Trifolium & Clover/trefoil & $\begin{array}{l}F . \text { avenaceum, } F \text {. } \\
\text { culmorum, } \\
\text { F. graminearum }\end{array}$ & Not indicated & [64] \\
\hline Urticaceae D & Urtica dioica $\mathrm{L}$. & Nettle & $\begin{array}{l}F \text {. avenaceum, } F \text {. } \\
\text { culmorum, } F . \\
\text { sambucinum }\end{array}$ & Stem base & {$[62]$} \\
\hline Scrophylariaceae D & Veronica persica & Speedwell & F. graminearum & Stem base & {$[62]$} \\
\hline Violaceae D & $\begin{array}{l}\text { Viola } \\
\text { Murray }\end{array}$ & Field violet & $\begin{array}{l}F . \text { avenaceum, } F . \text { poae, } \\
F . \text { culmorum, } F . \\
\text { graminearum, } F \text {. } \\
\text { sambucinum }\end{array}$ & Stem base & [62] \\
\hline Cryophyllaceae D & Dianthus & Carnation & $\begin{array}{l}F \text {. avenaceum, } F . \\
\text { culmorum, } F \text {. poae, } F \text {. } \\
\text { graminearum }\end{array}$ & Not indicated & {$[64]$} \\
\hline
\end{tabular}


2104 Figure 2: Chemical structures of trichotecenes, fumonisin B1 and zearalenone.

\section{Trichothecenes}

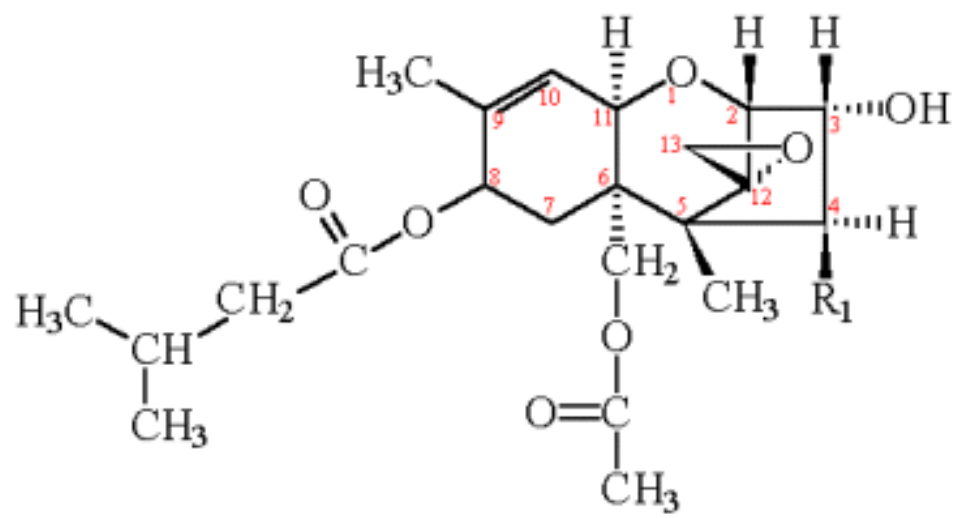

Type A trichothecenes: $\quad \mathrm{T}-2(\mathrm{R} 1=\mathrm{OAc})$

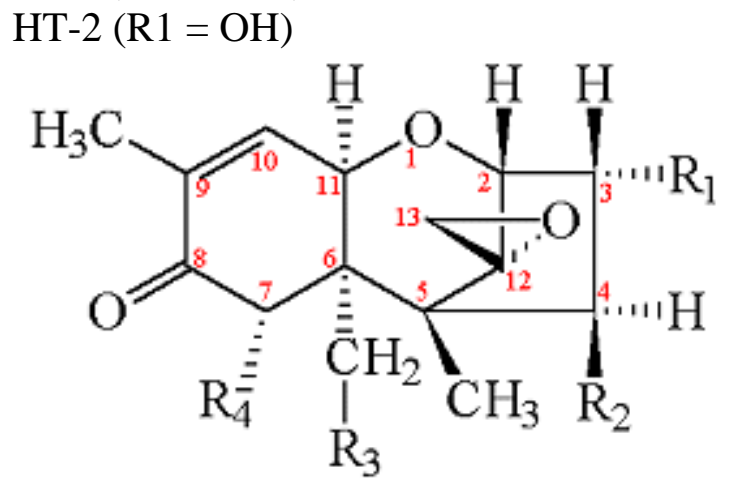

Type B trichothecenes: $\quad \mathrm{DON}(\mathrm{R} 1=\mathrm{OH}, \mathrm{R} 2=\mathrm{H}, \mathrm{R} 3=\mathrm{OH}, \mathrm{R} 4=\mathrm{OH})$

$\mathrm{NIV}(\mathrm{R} 1=\mathrm{OH}, \mathrm{R} 2=\mathrm{OH}, \mathrm{R} 3=\mathrm{OH}, \mathrm{R} 4=\mathrm{OH})$

2107

2108

2109

\section{Fumonisin $\mathrm{B}_{1}$}<smiles>CCCCC(C(=O)OCC(=O)O)C(OC(=O)CC(O)CC(=O)O)C(CC(C)CC(O)CCCCC(O)CC(O)C(C)N)C(=O)O</smiles>

2110

\section{Zearalenone}<smiles>CO[C@H](C)CCCC(=O)CCC/C=C/c1cc(O)cc(O)c1C(=O)O</smiles> 